\title{
The impact of Saharan dust on the particulate export in the water column of the North Western Mediterranean Sea
}

\author{
E. Ternon ${ }^{1,2}$, C. Guieu ${ }^{1,2}$, M.-D. Loÿe-Pilot ${ }^{3}$, N. Leblond ${ }^{1}$, E. Bosc ${ }^{4}$, B. Gasser ${ }^{4}$, J.-C. Miquel ${ }^{4}$, and J. Martín ${ }^{4}$ \\ ${ }^{1}$ INSU-CNRS, UMR 7093, Laboratoire d'océanographie de Villefranche, 06230 Villefranche-sur-Mer, France \\ ${ }^{2}$ Université Pierre et Marie Curie-Paris 6, UMR 7093, Laboratoire d'océanographie de Villefranche, 06230 \\ Villefranche-sur-Mer, France \\ ${ }^{3}$ CERES-ERTI, Ecole Normale Supérieure, Paris, France \\ ${ }^{4}$ IAEA Marine Environment Laboratories, Monaco
}

Received: 27 October 2009 - Published in Biogeosciences Discuss.: 17 November 2009

Revised: 12 February 2010 - Accepted: 19 February 2010 - Published: 2 March 2010

\begin{abstract}
Simultaneous measurements of atmospheric deposition and of sinking particles at 200 and $1000 \mathrm{~m}$ depth, were performed in the Ligurian Sea (North-Western Mediterranean) between 2003 and 2007, along with phytoplanktonic activity derived from satellite images. Atmospheric deposition of Saharan dust particles was very irregular and confirmed the importance of sporadic high magnitude events over the annual average $\left(11.4 \mathrm{~g} \mathrm{~m}^{-2} \mathrm{yr}^{-1}\right.$ for the 4 years). The average marine total mass flux was $31 \mathrm{~g} \mathrm{~m}^{-2} \mathrm{yr}^{-1}$, the larger fraction being the lithogenic one $(\sim 37 \%)$. The marine total mass flux displayed a seasonal pattern with a maximum in winter, occurring before the onset of the spring bloom. The highest POC fluxes did not occur during the spring bloom nor could they be directly related to any noticeable increase in the surface phytoplanktonic biomass. Over the 4 years of the study, the strongest POC fluxes were concomitant with large increases of the lithogenic marine flux, which had originated from either recent Saharan fallout events (February 2004 and August 2005), from "old" Saharan dust "stored" in the upper water column layer (March 2003 and February 2005), or alternatively from lithogenic material originating from Ligurian riverine flooding (December 2003, Arno, Roya and Var rivers). Those associated export fluxes defined as "lithogenic events", are believed to result from a combination of forcing (winter mixing or Saharan events, in particular extreme ones), biological (zooplankton) activity, and also organic-mineral aggregation inducing a ballast effect. By fertilising the surface layer, mixed Saharan dust events were shown to be able to induce "lithogenic events" during the stratification period. These events would
\end{abstract}

be more efficient in transferring POC to the deeper layers than the spring bloom itself. The extreme Saharan event of February 2004 exported $\sim 45 \%$ of the total annual POC, compared to an average of $\sim 25 \%$ for the bloom period. This emphasises the role played by these "lithogenic events", and in particular those that are induced by the more extreme Saharan events, in the carbon export efficiency in the Northwestern Mediterranean Sea.

\section{Introduction}

The Mediterranean Sea is a semi-enclosed basin receiving one of the highest rates of aeolian material deposition in the world (Guerzoni et al., 1999). It receives mineral dust from the Sahara desert in the form of strong pulses, and also continuous anthropogenic aerosol inputs from industrial and domestic activities on both sides of the basin. It also receives lithogenic material from coastal margins and rivers which contribute to the overall pool of lithogenic particles in the water column.

Recent studies have shown the importance of lithogenic particles in the export of the organic matter through the aggregation process (Hamm, 2002; Passow and De la Rocha, 2006; Ploug et al., 2008). Nevertheless, the physical role of large sporadic inputs of mineral dust during extreme Saharan dust events still remains poorly documented.

Published by Copernicus Publications on behalf of the European Geosciences Union. 


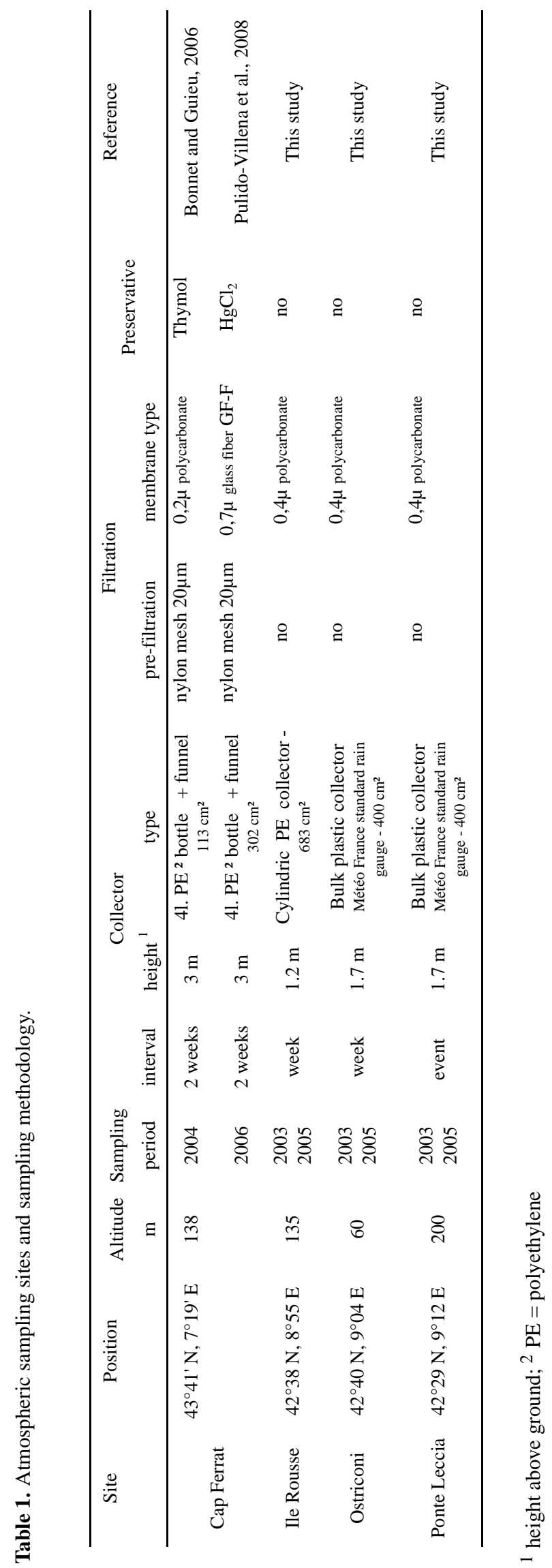




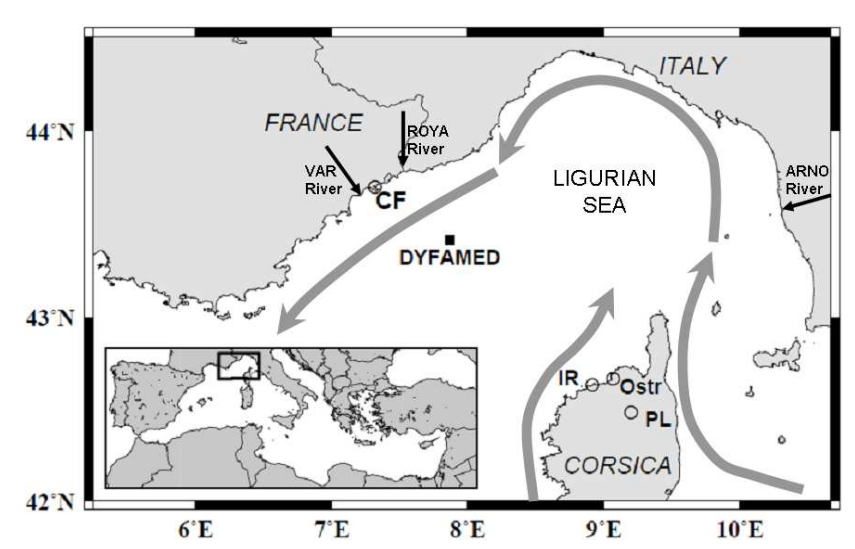

Fig. 1. Atmospheric and marine sampling sites. (Details on each site are available in Table 1; Ostr=Ostriconi; IR = Ile Rousse; $\mathrm{PL}=$ Ponte Leccia; $\mathrm{CF}=\mathrm{Cap}$ Ferrat). Circulation of surface water masses are illustrated by grey arrows. Ligurian rivers are illustrated by black arrows.

The Mediterranean Sea is characterized by strong stratification of the upper water column during at least five months of the year, occurring during the summer period, during which time the atmosphere then becomes the main external source of nutrients for the water surface mixed layer (see Guieu et al., 2010). By influencing the marine nutrient cycle and hence the nutrient budgets of nitrogen, phosphorus, iron (Loÿe-Pilot et al., 1990; Markaki et al., 2003; Krom et al., 2004; Bonnet and Guieu, 2006), these atmospheric inputs can impact on the heterotrophic (Thingstad et al., 1998; Pulido-Villena et al., 2008) and autotrophic production (Klein et al., 1997; Kouvarakis et al., 2001; Bonnet et al., 2005; Guieu et al., 2010) of the Mediterranean Sea. The biological production depends in part on the atmospheric inputs, and so therefore the marine particulate flux should also be indirectly linked to atmospheric deposition via its dependence on the biological production. This is in addition to its more direct link via the sedimentation of insoluble atmospheric particles.

The proximity and the diversity of aerosol sources, as well as the biogeochemistry of the surface layer, make the Mediterranean Sea an excellent natural laboratory to study the transfer of atmospheric lithogenic material and its potential role in the export of carbon. This 4-year time-series of both atmospheric and marine fluxes allows us to investigate (i) the effect of the atmospheric lithogenic deposition on the intensity and composition of the marine flux, (ii) the response of the biota to atmospheric inputs, and the associated marine flux occurring during the summer stratified period, and (iii) the role of lithogenic particles in the transfer of organic matter from the surface to the deeper layers of the water column.

\section{Materials and methods}

\subsection{Atmospheric sampling}

Bulk atmospheric deposition samples were collected at coastal sampling sites located on both sides of the Ligurian Sea (Fig. 1): Cap Ferrat on the continental shore line for the years 2004 and 2006 (Bonnet and Guieu, 2006; PulidoVillena et al., 2008), and at three sites in Corsica (Ostriconi, Ile Rousse and Ponte Leccia) for the years 2003 and 2005. Insoluble particulate atmospheric deposition was obtained by filtration of the samples onto membrane filters (see Table 1 for details) and then determination by weighing. The visual inspection of the filters allows discriminating the origin of long range transported atmospheric particulate matter (Loÿe-Pilot and Martin, 1996). Saharan dust corresponds to red clayey silts whereas particulate matter of anthropogenic origin is made of "black material", which is mainly black carbon (Loÿe-Pilot et al., 1986, 1990). In the case of mixed events with particulate matter of both origins (Loÿe-Pilot and Morelli, 1988; Lö̈e-Pilot et al., 1990) the weight of the polluted component, generally very low ( $<2 \mathrm{mg}$ on filters), was estimated and subtracted from the total weight in order to obtain the contribution of Saharan material.

The Saharan dust fallout is very irregular (Loÿe-Pilot et al., 1986; Loÿe-Pilot and Martin, 1996), and varied from 0.05 to $22 \mathrm{~g} \mathrm{~m}^{-2}$ for different events during the study period. The atmospheric sampling sites were considered as representative of the atmospheric deposition actually depositing in the central Ligurian Sea (Fig. 1).

\subsection{Marine sampling}

Since 1988, marine settling particulates have been collected at the DYFAMED site $\left(43^{\circ} 25^{\prime} \mathrm{N} 07^{\circ} 52^{\prime} \mathrm{E}\right)$ with 2 multisampling cylindrical sediment traps (Technicap PPS 5, height of $2.3 \mathrm{~m}$-collection surface of $1 \mathrm{~m}^{2}$ ) moored at $200 \mathrm{~m}$ and $1000 \mathrm{~m}$. This time-series site (http://www.obs-vlfr.fr/sodyf/) is located in an open ocean area $($ depth $=2330 \mathrm{~m}), 50 \mathrm{~km}$ offshore from the French coast and $130 \mathrm{~km}$ from Corsica. Data from the upper trap $(200 \mathrm{~m})$ were mainly considered in our study in order to relate observations of a potential increase in primary production induced by atmospheric deposition in the surface mixed layer. Data from the 1000 m sediment traps have only been used on an ad hoc basis.

The 24 trap collector cups were filled with a solution of $2 \%$ buffered formaldehyde in filtered seawater in order to prevent in situ microbial degradation and grazing by swimmers. Traps were set to sample sinking particles for consecutive periods ranging between 7 and 15 days. After retrieval of the traps (operated by IAEA up to November 2005, and then by LOV laboratory (Service National "Cellule Piège" INSU), the samples were stored in the dark at $4{ }^{\circ} \mathrm{C}$, until processed. Swimmers were identified and carefully removed, first by sieving through 1500 and $160 \mu \mathrm{m}$ mesh and then by 
handpicking the remainder under a binocular microscope. Any visible material attached to the swimmers was carefully removed as best as possible, to avoid biasing the particulate flux result. The remaining sample was desalted with ultrapure water and freeze-dried for future analyses. Mass flux was measured by weighing the freeze-dried sample five times with the accuracy of the weighing being about $1 \%$ over the whole data series (Miquel et al., 1994).

\subsection{Particulate matter analysis}

Carbon and nitrogen: For the samples treated at the IAEA, total carbon and nitrogen were analysed in duplicates using a VarioEL (CHN) elemental microanalyser on 2-3 mg aliquots of dry samples (Miquel et al., 1994). For samples treated at LOV, the concentration of total carbon and nitrogen was analysed in triplicate with a Perkin Elmer 2400 elemental analyser on 3-4 mg sub-samples of the desiccated samples, all according to Guieu et al. (2005).

Aluminium and calcium were analyzed by ICP-AES Jobin Yvon (JY 138 "Ultrace"), on acid digested samples. The detection limit of the apparatus, defined as 3 times the standard deviation of 10 measurements of the blank ( 9 ppb for aluminium and $4 \mathrm{ppb}$ for calcium), was well below the lowest concentration of the digested aliquot. The acid digestion was performed in $7 \mathrm{ml}$ Teflon flasks inside an oven $\left(150^{\circ} \mathrm{C}\right)$ and "suprapur" acids were added to $20 \mathrm{mg}$ of sample, following two steps $\left(1 \mathrm{~mL} 65 \% \mathrm{HNO}_{3}\right.$, and then $500 \mu \mathrm{L} 65 \% \mathrm{HNO}_{3}$, + $500 \mu \mathrm{L}$ of $40 \% \mathrm{HF})$. After each treatment, samples were oven heated at $150^{\circ} \mathrm{C}$ for $5 \mathrm{~h}$ (see Journel, 1998). Eight aliquots of both blanks and certified reference material (GBW07313: marine sediment from National Research Centre for Certified Reference Materials of China) were digested and analyzed in the same conditions. Results were consistent for the blanks (9 ppb for aluminium and $4 \mathrm{ppb}$ for calcium), and also for the reference material (recovery being $95 \pm 1 \%$ for aluminium and $96 \pm 2 \%$ for calcium, $n=8$ ).

\section{Reconstitution of the different fractions}

Elemental analyses were used to calculate the 4 main fractions of the collected material: carbonates, organic matter, lithogenic material and opal.

Carbonates. For samples treated at the IAEA the organic carbon was measured, after removal of carbonates (1M Phosphoric Acid), by CHN analysis as described above. The inorganic carbon was estimated as the difference between total and organic carbon and the carbonate fraction was calculated as $\mathrm{CaCO}_{3}=\mathrm{PIC} \times 8.33$. For samples treated at the LOV laboratory the carbonate fraction was determined from particulate calcium concentration measured by ICP-AES $\left(\mathrm{CaCO}_{3}=2.5 \times \mathrm{Ca}\right)$. Particulate inorganic carbon was then deduced from the carbonate fraction $\left(\mathrm{PIC}=0.12 \times \mathrm{CaCO}_{3}\right)$.

Organic matter. For samples treated at the IAEA, the particulate organic carbon (POC) was analysed by a CHN el- emental analyser, as mentioned above. Whereas for those treated at the LOV, the POC was calculated by subtracting the inorganic particulate carbon from the total carbon. The organic matter fraction (OM) was calculated as $2 \times(\%$ POC).

The lithogenic fraction was estimated from the particulate aluminium concentrations with 3 different assumptions for the aluminium (Al) content of lithogenic particles: $\mathrm{Al}$ concentrations are (i) typical of the upper continental crust ( $\mathrm{Al}=7.74 \%$, Wedepohl 1995), (ii) influenced by their Saharan origins ( $\mathrm{Al}=7.1 \%$, Guieu et al., 2002), or (iii) typical of riverine particles ( $\mathrm{Al}=9.4 \%$, Martin and Windom, 1991). Therefore, a range-value of the lithogenic fraction is given using these 3 concentrations.

The opal fraction was calculated as the difference between the total mass, and the sum of the other components $\left(\mathrm{CaCO}_{3}+\mathrm{OM}+\mathrm{Lithogenic}\right.$ material). Here again, a range is given, resulting from the range of the lithogenic fraction.

\subsection{Additional in situ and satellite data}

Daily surface chlorophyll concentrations estimated from the NASA sensor MODIS, using reprocessing \#4, (carried by AQUA), were spatially averaged by considering all the data from a square of $10 \mathrm{~km}^{2}$ (around 9 pixels) surrounding the DYFAMED site. Despite the missing data due to clouds, the time series, from March 2003 to end of 2007, reached a temporal cover of up to $60 \%$ during that period.

Salinity and water temperature, measured routinely by CTD casts between 0 and $200 \mathrm{~m}$ depth during the monthly DYFAMED surveys $\left(43^{\circ} 25^{\prime} \mathrm{N}, 7^{\circ} 52^{\prime} \mathrm{E}\right.$, http://www.obs-vlfr. fr/sodyf/), and BOUSSOLE cruises ( $43^{\circ} 22^{\prime} \mathrm{N}, 7^{\circ} 54^{\prime} \mathrm{E}$, http: //www.obs-vlfr.fr/Boussole/), were used to estimate the mixed layer depth. During these cruises, biological measurements such as pigment concentrations were also determined and those discrete data were used to help interpret our results. Physical data such as air and sea surface temperature, sea surface salinity, as well as wind speed and direction were continuously recorded by the Météo France Buoy (close to the DYFAMED site, $43^{\circ} 38^{\prime} \mathrm{N}, 7^{\circ} 83^{\prime} \mathrm{E}$, http: //www.meteo.shom.fr/real-time/html/dyfamed.html).

French riverine data (Var and Roya) were obtained from the free access website of the French governmental hydrological office (http://www.hydro.eaufrance.fr/). The Italian river data (Arno) were obtained from the Servizio Idrologico Regionale - Centro Funzionale - of the Regione Toscana (G. Fiorini, personal communication).

\section{Results}

\subsection{Atmospheric flux}

During the 4 years of this study, Saharan dust events covered a huge range of frequency and intensity. Very low $\left(0.05 \mathrm{~g} \mathrm{~m}^{-2}\right)$ dust flux events occurred relatively often (27 events in 4 years) but there was only one extreme event 


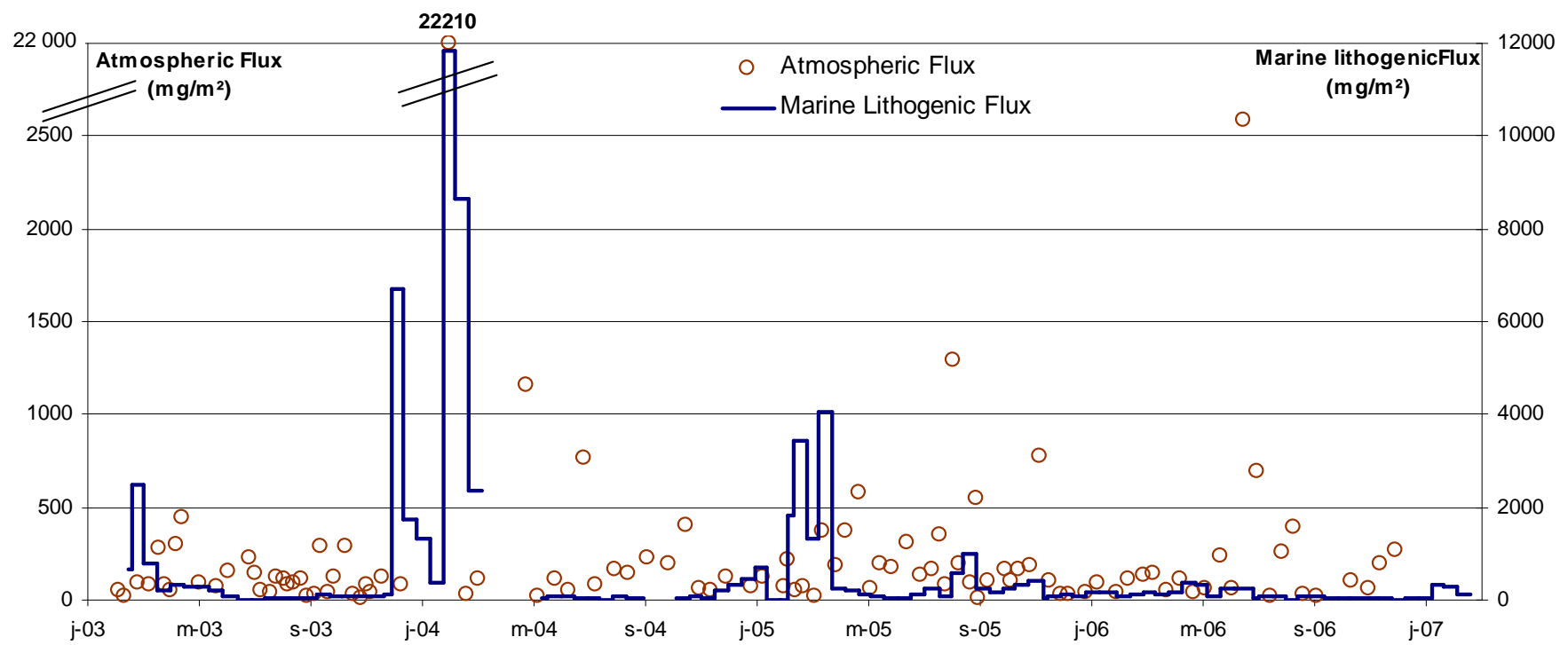

Fig. 2. 4 years time series of simultaneous marine and atmospheric lithogenic fluxes $\left(\mathrm{mg} \mathrm{m}^{-2}\right)$ in the Ligurian Sea (Atmospheric stations: Cap Ferrat and Corsica, marine station: DYFAMED site, $200 \mathrm{~m}$ depth).

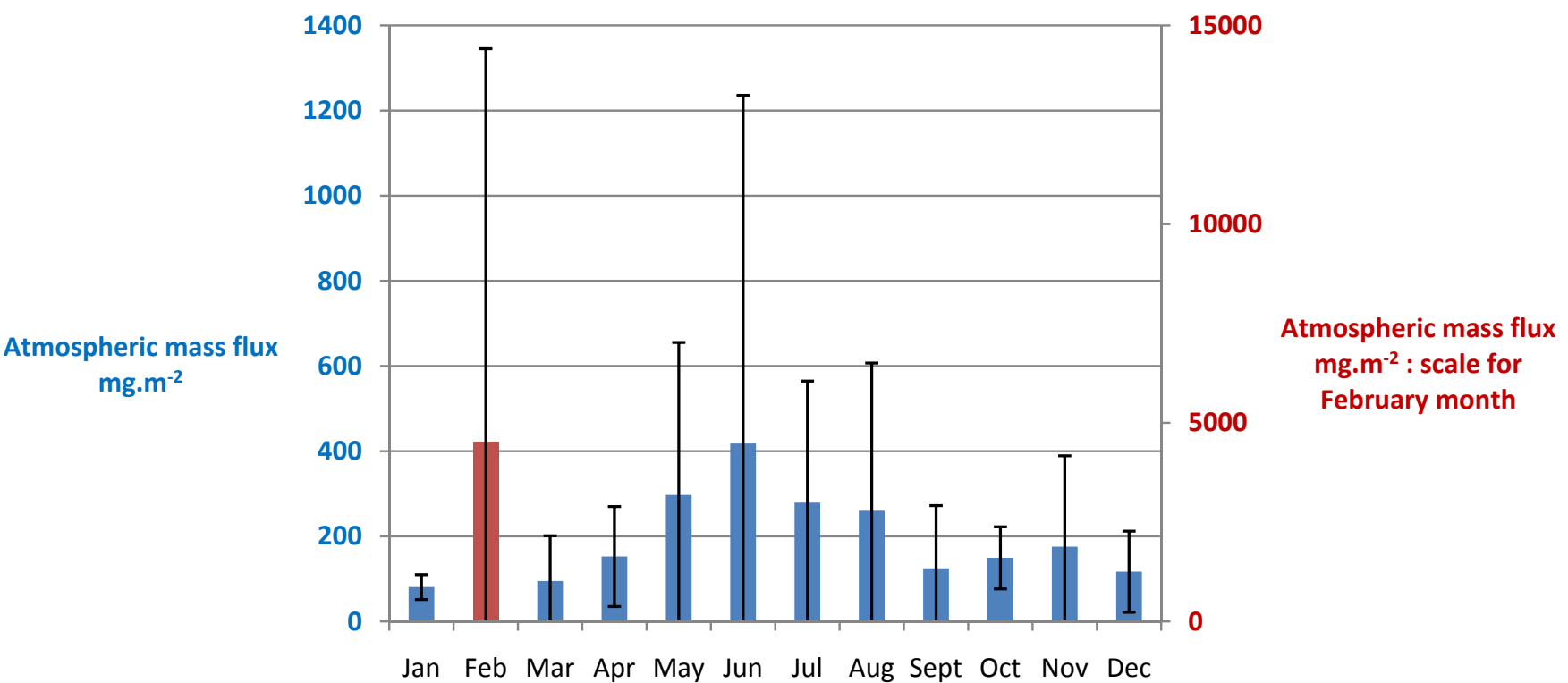

Fig. 3. Monthly average over the 4 years of the atmospheric deposition of insoluble particles. (The scale for February, on the right $\mathrm{Y}$ axis, is different in order to take into account the extreme Saharan event of February 2004. The error bars represent the standard deviation of the mean monthly values).

$\left(22 \mathrm{~g} \mathrm{~m}^{-2}\right)$, (Fig. 2). That particular Saharan event represented almost $90 \%$ of the Saharan input reported for the whole of 2004 at the Cap Ferrat site. The importance of a single event as part of the annual flux is consistent with previous observations by Loÿe-Pilot and Martin (1996). The monthly dust deposition during the study period shows a strong interannual variability (Fig. 3). The average annual dust flux over the 4 years $\left(11.4 \mathrm{~g} \mathrm{~m}^{-2} \mathrm{y}^{-1}\right)$ is very similar to the one observed in Corsica for the period 1984-1994 (12.5 $\mathrm{g} \mathrm{m}^{-2} \mathrm{y}^{-1}$,
Loÿe-Pilot and Martin, 1996). Most of the dust deposition occurred as wet deposition. This is consistent with LoÿePilot and Martin (1996) who showed that more than $95 \%$ of the Saharan events in Corsica are associated to wet deposition. 


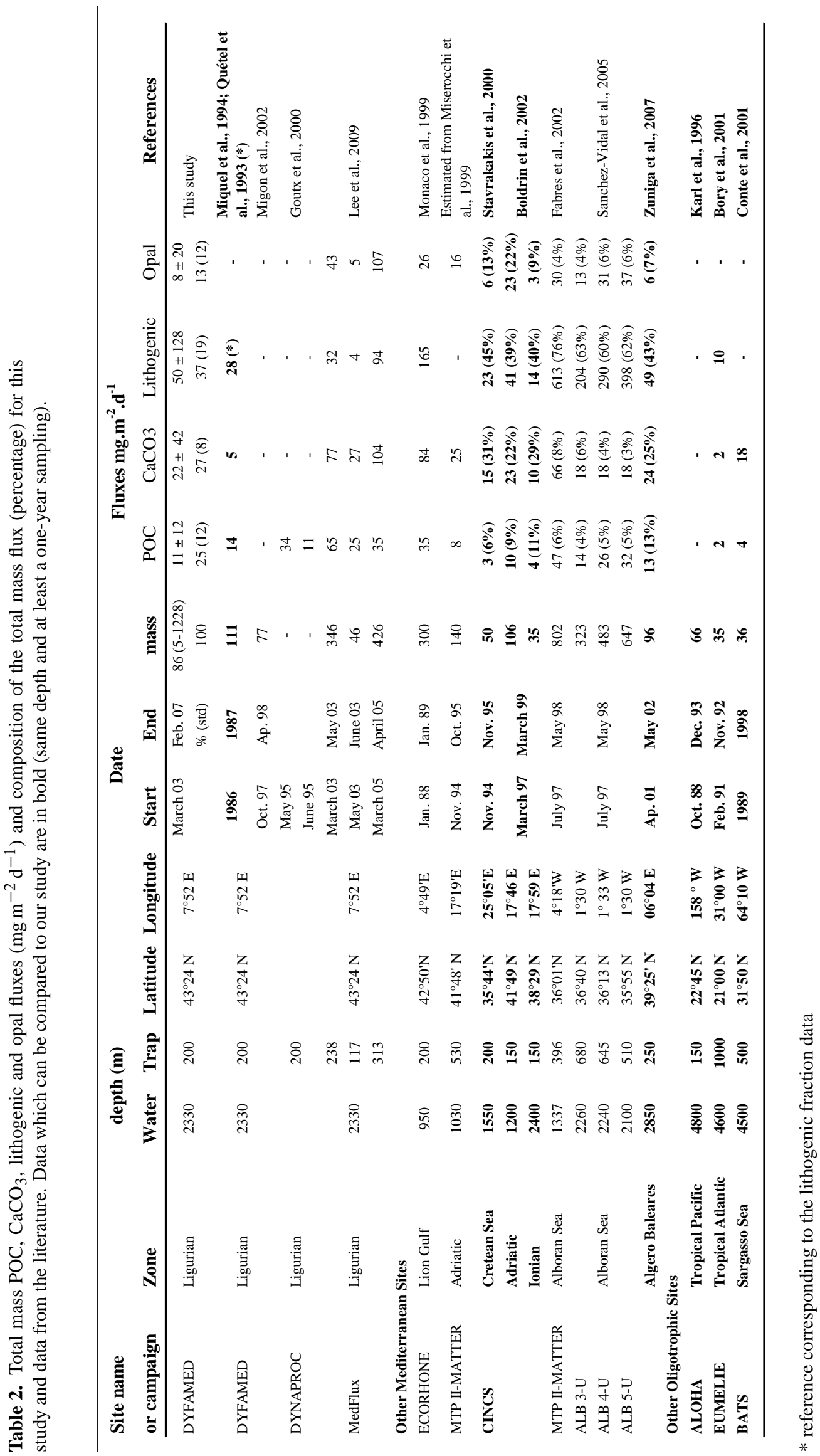




\subsection{Hydrological and biological features of the study site}

Monthly cruises at the DYFAMED site were monitored since 1991. This site is characterized by important seasonal variations in both hydrological and biological features (Marty et al., 2002). The hydrological seasonality is characterized by a vertical mixing period that generally occurs from late December until late March (winter mixing), and a period of strong thermal stratification ( $\sim 10$ to $20 \mathrm{~m}$, D'Ortenzio et al., 2005) usually from June to October, which is defined as summer stratification. The maximum of the winter mixing generally occurs in February and reaches $\sim 150-200$ m deep (Marty et al., 2002). The biological activity within the water column is driven by the hydrology, when the winter mixing brings nutrients into the surface layers, with a spring bloom generally initiated in early March, a peak in April and ending in late May (Marty et al., 2002; Bosc et al., 2004). The beginning of the bloom is dominated by large and opportunistic phytoplanktonic cells (diatoms), followed later by smaller cell species. Later in the season, during the stratification period, the biomass declines and is dominated by smaller picoplankton. The chlorophyll- $a$ maximum is then found at greater depth $(30-50 \mathrm{~m})$, following the establishment of a deeper nutricline layer (Marty et al., 2002).

The evolution of the hydrology during this study was generally consistent with the pattern described in Marty et al. (2002). However, the years 2004, 2005 and especially 2006 were characterized by strong mixing events with mixing depths reaching 400,600 and $2300 \mathrm{~m}$, respectively (Fig. 4). Contrary to these, the years 2003 and 2007 were characterized by weak mixing ( $\sim 100$ to $150 \mathrm{~m}$ depth) that began in late January. Summer stratification was strong $(\sim 10 \mathrm{~m}$ depth) and similar for each year studied. As shown on Fig. 5a, the evolution of the biological features over this 4-years study is consistent with the pattern described by Marty et al. (2002), Bonnet and Guieu, (2006) and Bosc et al. (2004). According to pigment data (not shown) the succession of phytoplankton species was the same as previously described by these authors. Nevertheless, over the period, the intra-annual pattern and maximum intensity of the surface chlorophyll- $a$ concentration showed an important interannual variability (Fig. 5a).

\subsection{Marine flux}

\subsubsection{Marine total mass flux}

From 2003 to 2007, the total mass flux (TMF) was on average $86 \mathrm{mg} \mathrm{m}^{-2} \mathrm{~d}^{-1}$, and presented a strong temporal variability over the 4 years $\left(5-1228 \mathrm{mg} \mathrm{m}^{-2} \mathrm{~d}^{-1}\right.$, Fig. 5 b). If the DYFAMED site is oligotrophic most of the year, the total mass flux is higher than those reported for other openocean oligotrophic sites located far from continental influence, for example $66 \mathrm{mg} \mathrm{m}^{-2} \mathrm{~d}^{-1}$ at Station ALOHA (Karl et

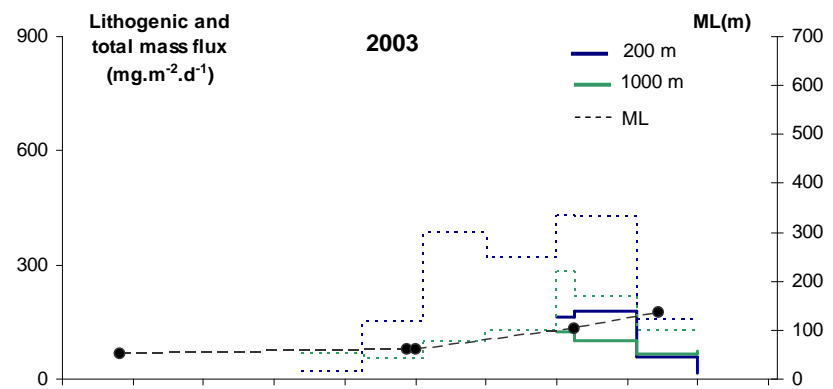

21-Nov 7-Dec 23-Dec 8-Jan 24-Jan 9-Feb 25-Feb 13-Mar 29-Mar 14-Apr 30-Apr

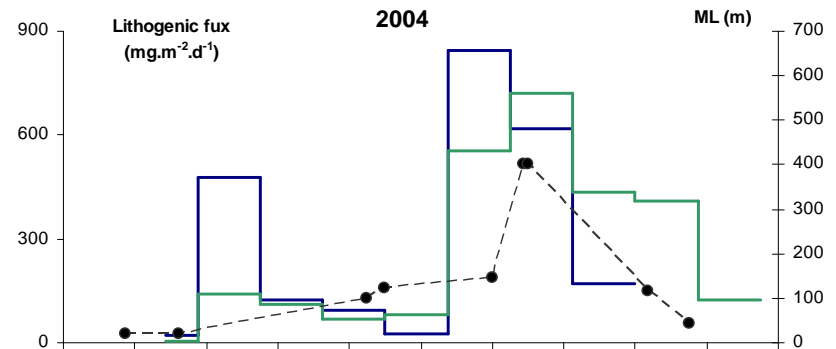

21-Nov 7-Dec 23-Dec 8-Jan 24-Jan 9-Feb 25-Feb 12-Mar 28-Mar 13-Apr 29-Apr

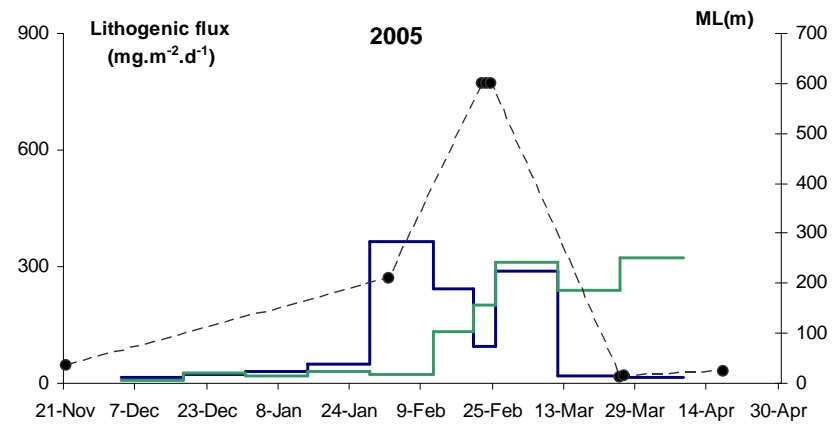

Fig. 4. Temporal evolution of the mixed layer (ML) depth (black dashed lines) and marine lithogenic fluxes $\left(\mathrm{mg} \mathrm{m}^{-2} \mathrm{~d}^{-1}\right)$ at 200 (blue lines) and 1000 (green lines) $m$ depth at the DYFAMED site for the years of high marine lithogenic fluxes during winter mixing (2003, 2004 and 2005). For the year 2003, lithogenic flux being not available before 13 March, the total mass flux (dotted lines) was plotted. The mixed layer was estimated from CTD data from the monthly DYFAMED cruises using the criteria that the density gradient between the surface and the base of the mixed layer is 0.05 (Lévy et al., 1998).

al., 1996), and $26 \mathrm{mg} \mathrm{m}^{-2} \mathrm{~d}^{-1}$ at BATS (Conte et al., 2001). Table 2 compares the data obtained at DYFAMED during this study with data from other Mediterranean sites and also from oceanic oligotrophic sites subject to noticeable atmospheric inputs (EUMELIE, BATS). However, the comparison between all these studies remains difficult as the sampling depths and duration were highly variable, with some studies not covering the key periods such as the spring bloom, the stratification period or the winter mixing. As compared to studies covering at least one year, our data are consistent with the values reported for similar depths, at different Mediterranean sites: $111 \mathrm{mg} \mathrm{m}^{-2} \mathrm{~d}^{-1}$ for the same site 


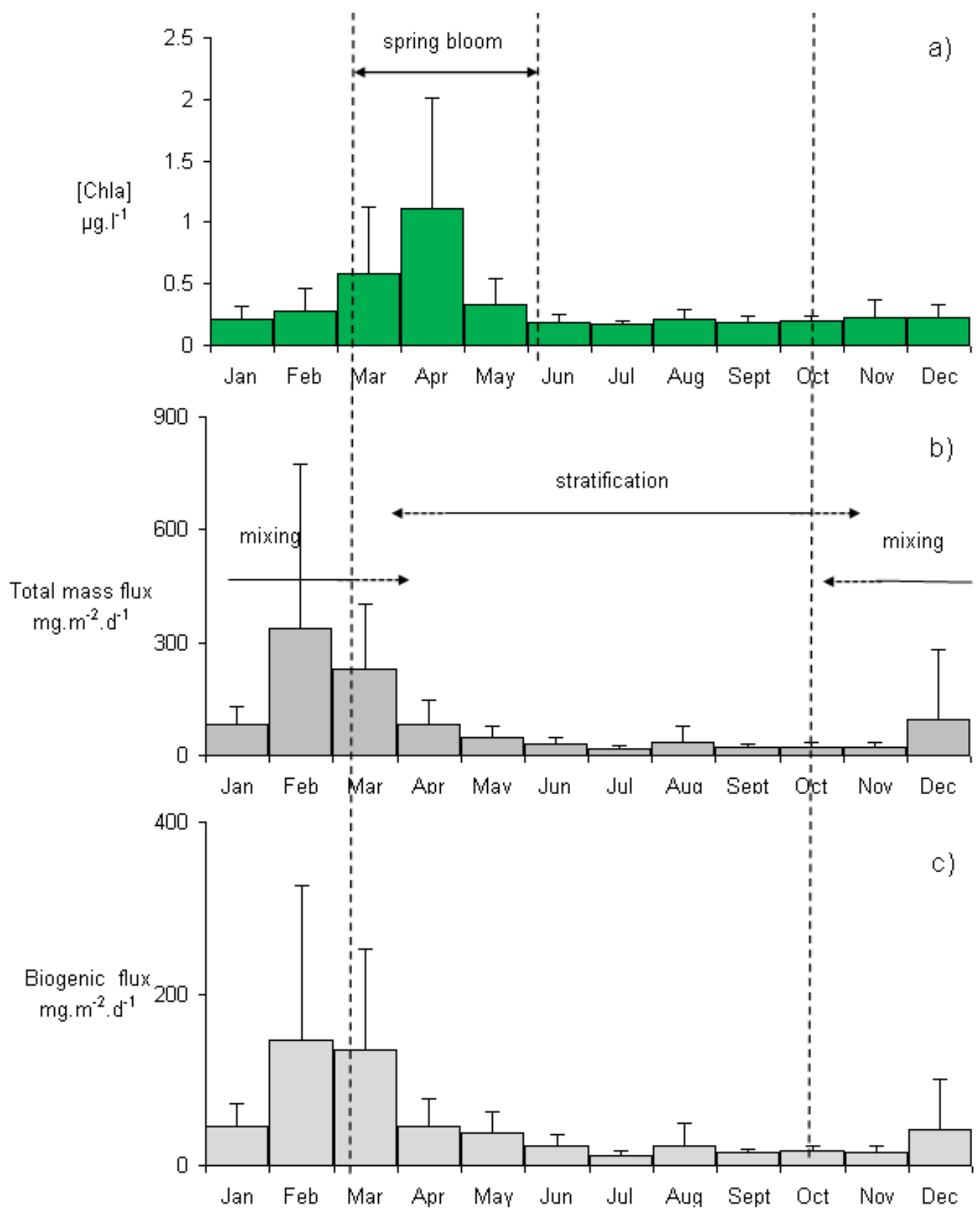

Fig. 5. Monthly average over the 4 years of (a) the surface chlorophyll- $a$ concentration $\left(\mu \mathrm{g} 1^{-1}\right)$ estimated from MODIS ocean color sensor measurements (pigment data are not shown), (b) the marine total mass flux at $200 \mathrm{~m}\left(\mathrm{mg} \mathrm{m}^{-2} \mathrm{~d}^{-1}\right)$, and (c) the marine biogenic $\left(\mathrm{CaCO}_{3}\right.$ + Opal + OM) flux at $200 \mathrm{~m}\left(\mathrm{mg} \mathrm{m}^{-2} \mathrm{~d}^{-1}\right)$. The error bars represent the standard deviation of the mean monthly values. High average and standard deviation for the February month are due to the extreme Saharan event of February 2004 which induced a total mass flux of $1228 \mathrm{mg} \mathrm{m}^{-2} \mathrm{~d}^{-1}$.

during the year 1987 (Miquel et al., 1994), $106 \mathrm{mg} \mathrm{m}^{-2} \mathrm{~d}^{-1}$ for the Adriatic (Boldrin et al., 2002) and $96 \mathrm{mg} \mathrm{m}^{-2} \mathrm{~d}^{-1}$, for the Algero-Provencal Basin (Zuniga et al., 2007). Some other Mediterranean sites characterized by different hydrological and biological features, present either higher or lower total mass flux values: 300 and $647 \mathrm{mg} \mathrm{m}^{-2} \mathrm{~d}^{-1}$ for respectively the Gulf of Lions and the Alboran Sea (Monaco et al., 1999; Sanchez-Vidal et al., 2005) and $35 \mathrm{mg} \mathrm{m}^{-2} \mathrm{~d}^{-1}$ for the Ionian Sea (Boldrin et al., 2002). 
Lee et al. (2009) measured the total mass flux in the same area and depths during the spring bloom, from March to May in 2003 and 2005, and at the beginning of the stratification period in May-June 2003, but with a different sampling device (a sampling surface of $0.0184 \mathrm{~m}^{2}$ vs. $1 \mathrm{~m}^{2}$ in this study) and a different sampling scheme (5 days vs. 14 days in this study). In the situation of the low fluxes (most of the time), the total mass flux was similar in both studies whereas in the situation with high fluxes (March 2003), the total mass flux measured by Lee et al. (2009) was twice that of this study ( $\sim 800$ and $430 \mathrm{mg} \mathrm{m}^{-2} \mathrm{~d}^{-1}$, respectively). This difference could have several causes such as spatial patchiness or over/under collection by respective sampling devices. If a sampling bias was the cause of the observed discrepancy, both the 200 and $1000 \mathrm{~m}$ traps would show a difference in flux. The comparison of the integrated total mass flux $\left(\mathrm{mg} \mathrm{m}^{-2}\right)$ over the common periods (6 March to 6 May 2003, 14 May to 30 June 2003, and 4 March to 1 May 2005) indicated that fluxes described by Lee et al., were higher by a factor of 1.0 to 2.9 at $200 \mathrm{~m}$ and from 0.74 to 1.7 at $1000 \mathrm{~m}$. The discrepancy at 200 and $1000 \mathrm{~m}$, being of the same order of magnitude, reinforces the sampling bias hypothesis.

Over our 4 years study, the marine total mass flux at $200 \mathrm{~m}$ depth had a seasonal pattern (Fig. 5b) with the highest fluxes in winter ( $303 \pm 426 \mathrm{mg} \mathrm{m}^{-2} \mathrm{~d}^{-1}$, February) and lowest fluxes in summer $\left(16 \pm 10 \mathrm{mg} \mathrm{m}^{-2} \mathrm{~d}^{-1}\right.$, July). Such a pattern is consistent with the one previously described for the same site by Miquel et al. (1994). Fluxes were also high during the spring bloom period ( $72 \pm 121 \mathrm{mg} \mathrm{m}^{-2} \mathrm{~d}^{-1}$, in April). It is noteworthy that the maximum of the total mass flux occurred before the peak of the bloom. This is still true if we do not take into account the particular event of February 2004. The high values of the standard deviation for some months denote significant inter-annual variations of this pattern (i.e. February with a standard deviation $>100 \%$, Fig. 5b). However, the fluxes recorded during the year 2006 seem abnormal with very low fluxes in late winter and moderate fluxes during the spring bloom. The year 2006 was characterized by a very strong deep winter mixing (over the whole water column) associated with strong currents at $200 \mathrm{~m}$ depth $\left(>15 \mathrm{~cm} \mathrm{~s}^{-1}\right.$, and up to $30 \mathrm{~cm} \mathrm{~s}^{-1}$ ) (Service d'Observation, Observatoire Océanologique de Villefranche-sur-Mer).

\subsubsection{Composition of the marine flux}

\section{Average composition}

The relative average contributions of the major constituents (carbonates, organic matter, lithogenic material and opal) to the marine particulate flux are shown in Table 2. During the study, the marine particulate matter was composed of $27 \pm 8 \% \mathrm{CaCO}_{3}, 25 \pm 12 \% \mathrm{OM}, 37 \pm 19 \%$ lithogenic material, and $13 \pm 12 \%$ opal. A similar composition has already been reported for the Ligurian Sea at the same depth for the years 1986-1987 (Quétel et al., 1993; Miquel et al., 1994). The carbonate fraction could include a fraction of Saharan origin, as Saharan dusts may contain up to $20 \% \mathrm{CaCO}_{3}$ (Guieu et al., 2002). A high lithogenic contribution to the annual total mass flux has also been reported for other Mediterranean sites: $39 \%$ for both the Adriatic and Ionian seas (Boldrin et al., 2002) and 51\% for the Algero-Balearic basin (Zuniga et al., 2008). The remaining part of the flux in our study $(\sim 60 \%)$ represented by the sum of the biogenic fluxes (carbonates $+\mathrm{OM}+$ opal) was quite similar to values reported throughout the Mediterranean basin: 53\% (Boldrin et al., 2002), 52\% (Zuniga et al., 2008), and 55\% (Stavrakakis et al., 2000).

\section{Variability of the marine flux composition}

The seasonal pattern observed for the total mass flux is also valid for both lithogenic and biogenic fractions. The highest lithogenic fluxes occurred during the winter mixing period (265 $\pm 312 \mathrm{mg} \mathrm{m}^{-2} \mathrm{~d}^{-1}$ in February over the 4 years period), and the lowest during summer $\left(5 \pm 5 \mathrm{mg} \mathrm{m}^{-2} \mathrm{~d}^{-1}\right.$ in July).

For high mass fluxes (winter mixing), the lithogenic fraction is the dominant component of the total mass flux, whereas for low mass fluxes (stratification period), the biogenic fraction dominates, as already mentioned by Migon et al. (2002). This indicates that in winter the biological activity is not the main parameter controlling the total mass flux composition and intensity.

Reflecting the species succession during the spring bloom, the biogenic flux was mostly formed by opal at the beginning of the bloom (diatoms bloom in February-March) and then by carbonates (prymnesiophytes bloom in April-May). The dominant group of phytoplankton are the prymnesiophytes in the North Western Mediterranean Sea and this predominance is independent of the season (Marty et al., 2002). Thus, the carbonate fraction dominates the biogenic flux most of the time, and its contribution presents generally very little variation throughout the year. The highest fluxes of $\mathrm{CaCO}_{3}$ and $\mathrm{OM}$ were reached in February 2004 with respective values of 295 and $71 \mathrm{mg} \mathrm{m}^{-2} \mathrm{~d}^{-1}$. In contrast, lowest values for carbonates were observed in summer $2004\left(0.8 \mathrm{mg} \mathrm{m}^{-2} \mathrm{~d}^{-1}\right)$ and for OM in summer 2006 $\left(2 \mathrm{mg} \mathrm{m}^{-2} \mathrm{~d}^{-1}\right)$. On average, the highest biogenic fluxes occurred before the peak of the bloom (Fig. 6), at the end of the winter mixing $\left(122 \pm 144 \mathrm{mg} \mathrm{m}^{-2} \mathrm{~d}^{-1}\right.$ in February) and the lowest during the stratification period $\left(11 \pm 6 \mathrm{mg} \mathrm{m}^{-2} \mathrm{~d}^{-1}\right.$ in July). Only the year 2006 exhibited its highest biogenic fluxes during the spring bloom.

\section{Discussion}

It has been suggested that atmospheric deposition of mineral particles from the Saharan source may be the major source of terrigenous sediments in the offshore Mediterranean Sea (Loÿe-Pilot et al., 1986; Bergametti et al., 1989; Tomadin 


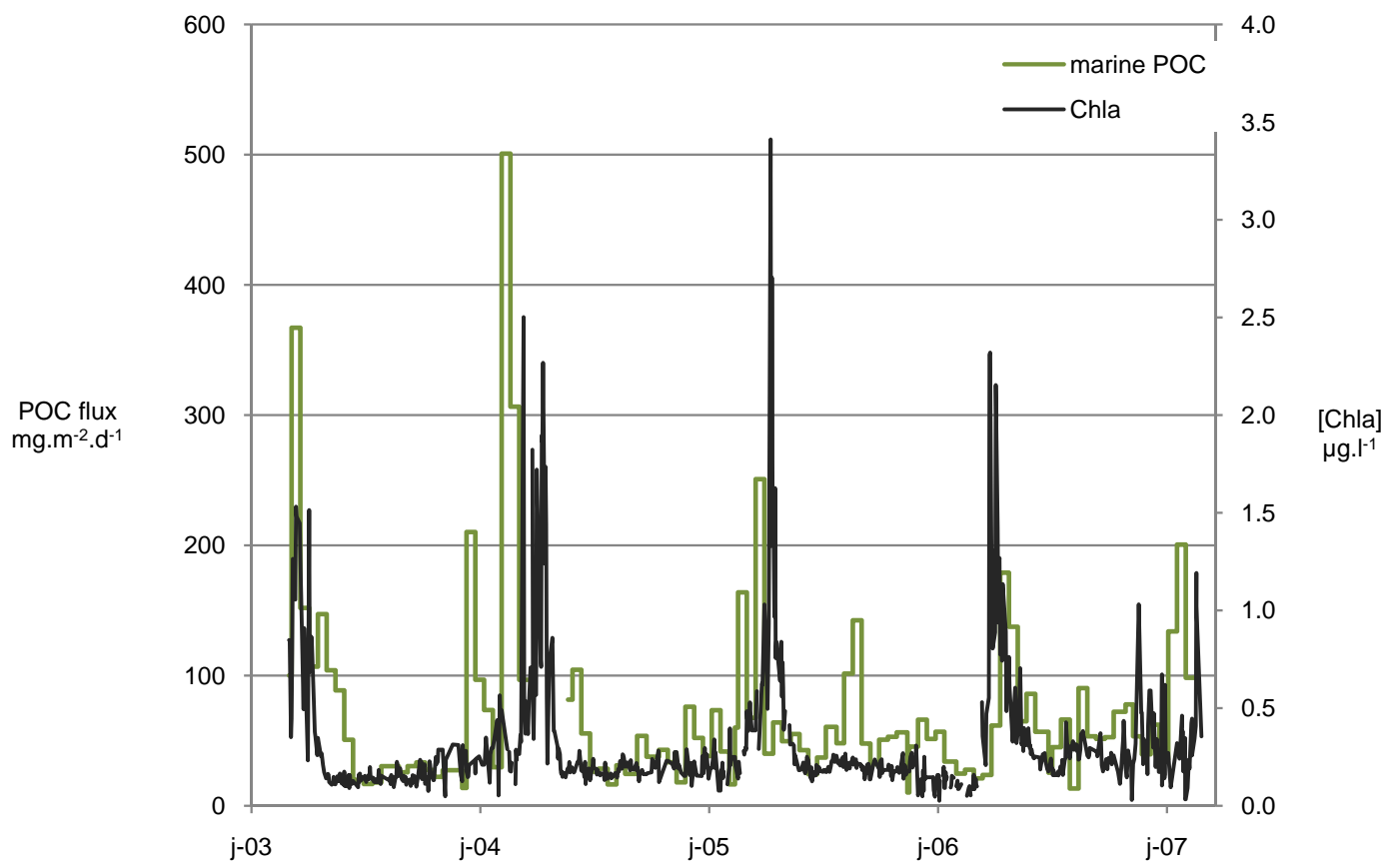

Fig. 6. Surface chlorophyll- $a$ concentration $\left(\mu \mathrm{g} \mathrm{L}^{-1}\right)$ estimated from MODIS ocean color sensor measurements, and POC export $\left(\mathrm{mg} \mathrm{m}^{-2} \mathrm{~d}^{-1}\right.$, in situ measurements) at $200 \mathrm{~m}$ depth (DYFAMED site).

and Lenaz, 1989) and thus would contribute to lithogenic particles trapped in the water column at the DYFAMED site (Buat-Menard et al., 1989; Quétel et al., 1993; Journel, 1998; Migon et al., 2002).

Although over the 4-years, the average of atmospheric and marine lithogenic fluxes were of the same order of magnitude (respectively $29 \pm 7 \mathrm{mg} \mathrm{m}^{-2} \mathrm{~d}^{-1}$ and $40 \pm 7 \mathrm{mg} \mathrm{m}^{-2} \mathrm{~d}^{-1}$ ), two different temporal trends can be observed when comparing both fluxes (Fig. 2). Atmospheric and marine lithogenic fluxes were in general not synchronous, preventing any direct temporal comparison. Because some marine lithogenic peaks observed throughout the time-series can be related to atmospheric deposition whereas others do not, three contrasting cases will be explored in the following discussion: (1) winter high marine lithogenic fluxes which were not related to direct or recent Saharan events (March 2003, and February 2005); (2) high marine lithogenic fluxes related to Ligurian riverine flooding rather than Saharan deposition (December 2003); and (3) high marine lithogenic fluxes following Saharan dust events (February 2004 and August 2005).

\subsection{Winter high marine lithogenic fluxes: March 2003 and February 2005}

Some high marine lithogenic fluxes that took place during winter mixing (March 2003 and February 2005) could not be related to direct nor recent atmospheric deposition. Winter mixing constitutes a period of high marine mass fluxes in this area (Miquel et al., 1994; Quétel et al., 1993;
Migon et al., 2002), and this was observed in our studies in March 2003 (430 $\mathrm{mg} \mathrm{m}^{-2} \mathrm{~d}^{-1}$ ) and February 2005 $\left(451 \mathrm{mg} \mathrm{m}^{-2} \mathrm{~d}^{-1}\right)$. Mass fluxes were mainly formed by lithogenic material ( $40 \pm 5 \%$ and $80 \pm 11 \%$ in 2003 and 2005, respectively) which was not related to an identified Saharan event (Fig. 2). Atmospheric mineral particles deposited during the previous months are reported to remain stored in the surface layers of the water column during the stratification period (Migon et al., 2002), along with dissolved organic carbon and small biogenic particles. These could then be rapidly exported when the stratification breaks down and winter mixing starts. The reasons why these mineral particles are exported during the winter mixing is still not fully understood. However, three mechanisms favouring the quick export of the particles from the surface layer to the deeper layers can be proposed: i) the vertical convection processes during winter which homogenise the superficial part of the water column (0-250 m; Marty et al., 2002), ii) the incorporation of mineral particles into faecal pellets (= biological aggregation; Burd and Jackson, 2009) as shown by Fowler et al. (1987) and Buat-Menard et al. (1989) which greatly contributes to the mass flux during the winter mixing (Miquel et al., 1994), and iii) the incorporation of mineral particles, acting as ballast, in organic aggregates (= physical aggregation; Burd and Jackson, 2009). These organic aggregates may be formed by either 'old' organic matter stored in the water column (Marty et al., 1994) or organic colloids such as TEP (transparent exocellular polysaccharides; Alldredge et al., 1993) generated by the emerging diatom blooms. 
The comparison of sediment trap data (200 and $1000 \mathrm{~m}$ depth) and the mixed layer depth temporal evolution (Fig. 4) shows that for the years 2003 and 2005, high marine fluxes were concurrent with the start of the deepening of the mixed layer. Although the mixed layer did not reach $1000 \mathrm{~m}$ depth, near concurrent high marine fluxes were observed at both 200 and $1000 \mathrm{~m}$ depths. It has been recently stated that the mixed layer deepening would act as a trigger for aggregation via the collision of particles and algal cells which takes place in the mixed layer (Jackson, 2008), rather than as a conveyor of particles. The formation and enhanced growth of aggregates would accelerate particulate removal by a massive and rapid sedimentation to the deeper layers.

It is also possible that dissolved aluminium could be scavenged by siliceous organisms (Mackenzie et al., 1978; Hydes, 1979; Gehlen et al., 2002), increasing the particulate aluminium flux during the period of early diatoms blooms; as a result, the lithogenic flux derived from particulate aluminium would have also included any dissolved aluminium (also from eolian origin - Measures, 1995; Han et al., 2008) and stored like Fe (Bonnet and Guieu 2006), in the mixed layer during the stratification period. Aluminium scavenging by diatoms could thus lead to an overestimation of marine lithogenic fluxes, which will be particularly significant at the beginning of the spring bloom.

\subsection{High marine lithogenic fluxes related to Ligurian river floods: December 2003}

In December 2003, a strong export of lithogenic particles (478 $\pm 67 \mathrm{mg} \mathrm{m}^{-2} \mathrm{~d}^{-1}$; Fig. 2) occurred at the very beginning of the winter mixing period (mixed layer between 20 and $90 \mathrm{~m}$ deep), but with no associated Saharan dust deposition. The DYFAMED site is believed to be most of the time a 1-D site, presenting thus a weak advection (Andersen and Prieur, 2000). However, in the case of very strong floods from the Ligurian rivers, the DYFAMED site may be influenced by those inputs (Béthoux and Prieur, 1983; Stemmann, 1998; and Stemmann et al., 2002), and this has also been observed on the ocean floor (Guidi-Guilvard, 2002).

Data from the three major Ligurian rivers show severe floods on the 1 November and 3 December 2003, while the high marine lithogenic flux was measured from the 21 December until the end of January 2004 (Fig. 7). If the high lithogenic flux recorded at DYFAMED is linked to inputs from those rivers, it means that the transit time necessary for a riverine particle to reach the DYFAMED site is at least 3 weeks. This time is consistent with the observation made by Béthoux and Prieur (1983) who showed that strong freshwater inputs in Italy can be transported by the Ligurian current within 3 weeks to as far as 30 nautical miles away from the French coast. Those findings were confirmed by Stemmann et al. (2002), who showed that according to the flow patterns of the Ligurian current, parts of those riverine inputs could reach the DYFAMED area. This means that in win- ter 2003-2004, a significant proportion of marine lithogenic material at the DYFAMED site originated from the riverine flooding, and that the advection of particulate matter from the coastal margins could explain that, in some years, the marine lithogenic flux can be higher than Saharan inputs alone.

\subsection{Marine lithogenic fluxes following Saharan dust events}

During the 4 years time series, 2 specific high marine lithogenic fluxes illustrated how a rapid transfer of Saharan particles can occur in very contrasting hydrological conditions.

\subsubsection{High marine lithogenic fluxes following the ex- treme Saharan event of February 2004}

Whilst the winter mixing process was high, an extreme Saharan dust input $\left(22.2 \mathrm{~g} \mathrm{~m}^{-2}\right)$ occurred in the early hours of 21 February 2004. The strong and rapid marine lithogenic export that followed the event was attributed to this Saharan dust fallout. Indeed, taking into account that the atmospheric deposition was not precisely measured at the DYFAMED site, the amount of lithogenic particles retrieved in the traps within the following month $(23 \mathrm{~g})$ was of the same order of magnitude as the Saharan deposition $\left(22.2 \mathrm{~g} \mathrm{~m}^{-2}\right)$ measured at Cap Ferrat. The marine lithogenic flux in February 2004 was the highest flux ever reported at the DYFAMED site (Buat-Menard et al., 1989; Quétel et al., 1993; Migon et al., 2002; Lee et al., 2009), and would have been made up of the new lithogenic particles brought in by the Saharan event. Indeed, the sedimentation of the December 2003 floods material washed out all the lithogenic particles that were stored in the surface layer during the previous stratification period. The lack of lithogenic particles in the mixed layer at the beginning of the winter mixing would have prevented the formation of any high marine lithogenic fluxes from early 2004 (Fig. 4) until the Saharan event occurred.

Several studies performed at the same site (Fowler et al., 1987; Buat-Menard et al., 1989) showed that aluminosilicate minerals are easily incorporated into faecal pellets or trapped in organic aggregates, thus enabling the possibility of a rapid export of lithogenic and organic material to the deeper water column, and implying that lithogenic particles do not sink following Stokesian settling rates. Indeed, Saharan particles were also directly transferred to $1000 \mathrm{~m}$ (Fig. 4), confirming very high sedimentation rates during such sporadic extreme dust events, with a minimal settling velocity of $100 \mathrm{~m} \mathrm{~d}^{-1}$ for $\sim 35 \%$ of the lithogenic material resulting from atmospheric deposition. At the same site, Armstrong et al. (2009), measured a settling velocity with an average of $353 \pm 76 \mathrm{~m} \mathrm{~d}^{-1}$ for the fast sinking particles. Thus, it is not surprising that more than half of the amount of the Saharan dust input was retrieved within less than 10 days at a depth of $200 \mathrm{~m}$. In addition, the near concurrent high 


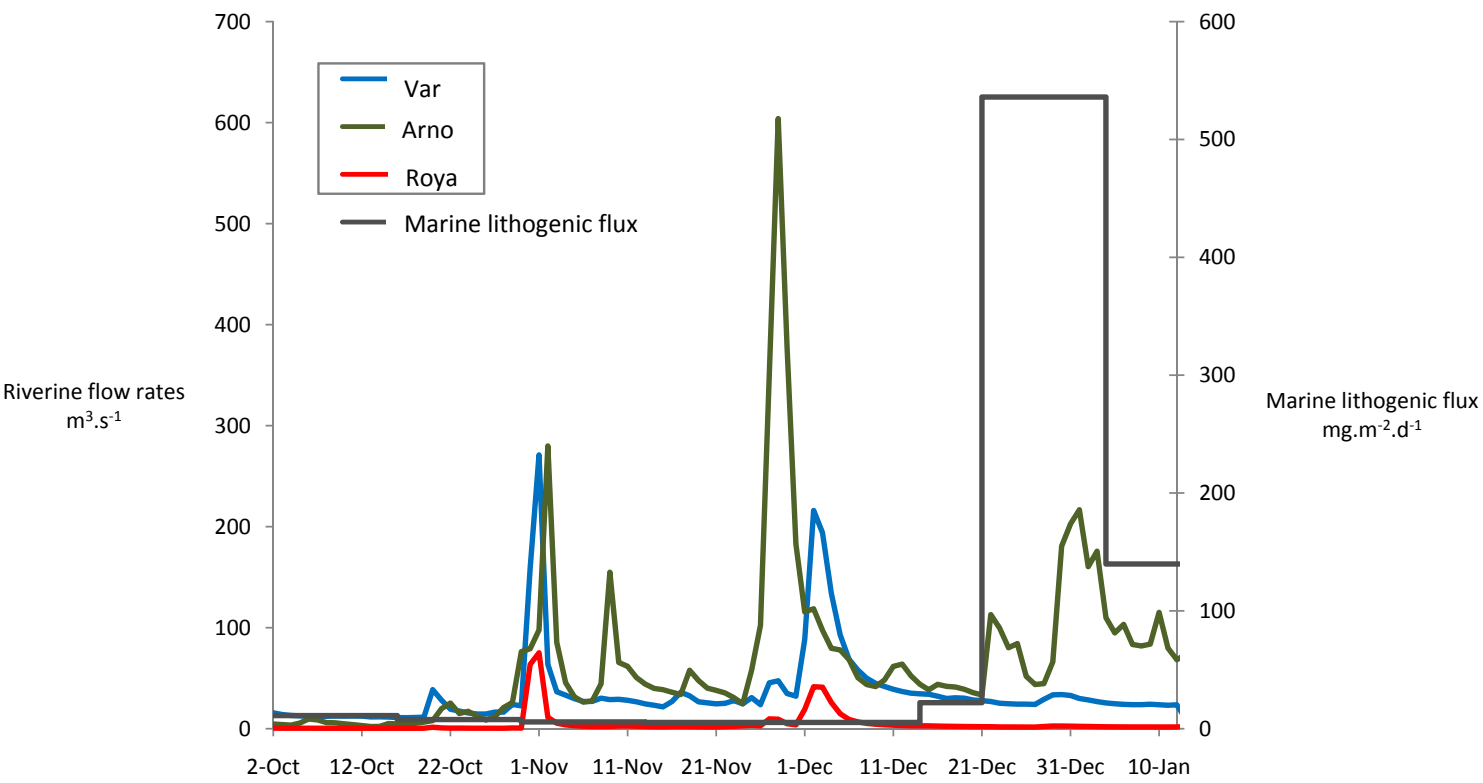

Fig. 7. Marine lithogenic flux in the Ligurian Sea at the DYFAMED site at $200 \mathrm{~m}\left(\mathrm{mg} \mathrm{m}^{-2} \mathrm{~d}^{-1}\right)$ and Ligurian rivers flow rates $\left(\mathrm{m}^{3} \mathrm{~s}-1\right)$ at the end of 2003 .

lithogenic flux measured at $1000 \mathrm{~m}$ depth (Fig. 4) confirms that for high fluxes, aluminium could be a good tracer of lithogenic material, despite the potential scavenging of dissolved aluminium onto silica.

\subsubsection{Induced fertilisation related to Saharan inputs during the stratification period in summer 2005}

A series of Saharan events in August 2005 (10th to 12th, and 18th) brought $\sim 2 \mathrm{~g} \mathrm{~m}^{-2}$ of mineral particles into the water column. An increase of the marine lithogenic fluxes was observed then during the following month (14 August to 11 September), which was actually quite surprising as generally the marine summer fluxes are low, with the well established stratification and the established thermocline layer acting to limit the downward transport of atmospheric material (Migon et al., 2002).

During that period, the atmosphere represents a significant influence on the biogeochemical cycles in the surface mixed layer, and provides the nutrients to be able to sustain "new" production (see for example Duce et al., 1991). Phosphorus is thought to be the limiting element in summer for both bacterioplankton and phytoplankton communities (Moutin et al., 2002; Bonnet et al., 2005; Pulido-Villena et al., 2008). Therefore, an input of "new" phosphorus released by atmospheric deposition to the P-depleted mixed layer would enhance the bacterial and the phytoplankton activity, given that there was sufficient $\mathrm{N}$ in the system to support this. The Saharan dust fallouts in August 2005 were accompanied by moderate winds (13 knots), and these were not sufficiently strong to disrupt the stratification or induce any injection of new nutrients from below the thermocline into the surface mixed layer. The dust fallout of the 11-12 August was also accompanied by convective rains, and the end of the event was typically a "mixed" event. In "mixed" rain events (LoÿePilot and Morelli, 1988; Loÿe-Pilot et al., 1990), anthropogenic aerosols are scavenged with Saharan dust, and their high inorganic nitrogen content and acidic/complexing components increase the dissolution of the inorganic phosphate of the Saharan particles to provide a notable input of bioavailable nutrients. According to values reported for "mixed rain" in other Mediterranean studies (Loÿe-Pilot et al., 1990; Herut et al., 1999; Migon and Sandroni, 1999), such an event would have bring $\sim 150-300 \mu \mathrm{mol} \mathrm{m}{ }^{-2}$ of nitrogen and $\sim 9-$ $19 \mu \mathrm{mol} \mathrm{m}^{-2}$ of phosphorus into the surface layer. By using the Redfield ratios (C:N:P=106:16:1), the calculated surface new primary production would have ranged from 12 to $24 \mathrm{mg} \mathrm{C} \mathrm{m}^{-2}$, and the chlorophyll- $a$ concentration from 0.04 to $0.08 \mu \mathrm{g} \mathrm{L}^{-1}$ (based on a C/Chl- $a$ ratio of 50; Guieu et al, 2010). The estimated dust-induced chlorophyll- $a$ concentration represented 20 to $40 \%$ of the surface chlorophyll- $a$ concentration observed at that time $\left(0.2 \mu \mathrm{g} \mathrm{L}^{-1}\right.$ - MODIS data, Fig. 6), but no increase was detectable from satellite data at that time. Theoretically, the amount of POC exported, following such a fertilisation, could have reached up to $24 \mathrm{mg}$ $\mathrm{C} \mathrm{m}^{-2}$. However, within 14 days after the dust event, the sediment traps recorded a much higher increase of the POC flux (140 $\mathrm{mg} \mathrm{C} \mathrm{m}^{-2}$; Fig. 6). This 3 fold increase of the POC export can be compared to the biogeochemical response observed after a dust deposition in the Atlantic oligotrophic gyre (Neuer et al., 2004), or in the North Pacific (Bishop et al., 2002), both attributed to dust-induced fertilisation of the surface mixed layer. In this present study, the amount of 
carbon induced by fertilisation would only explain $17 \%$ of the total amount of POC exported afterwards. In addition to freshly-produced POC, an export of the in situ OM, already present in the water column, would have occurred simultaneously. It is important to note that the organic matter brought by a Saharan event would not significantly contribute to the POC flux as organic carbon in Saharan dust only represents $0.43 \% \pm 0.02 \%$ of the particle mass (Ridame, 2001).

The fact that this dust-induced biological enhancement was not visible from satellite information could be due to the lack of sensitivity of the satellites in detecting very small chlorophyll- $a$ variations. Bonnet et al. (2005), reporting results from dust additions to microcosm experiments, observed a $\sim 0.02 \mu \mathrm{g} \mathrm{L}^{-1}$ increase in chlorophyll- $a$ concentration and showed that, despite such a small increase of the total Chl- $a$, primary production was positively enhanced by the dust fertilisation and was sustained by bigger phytoplankton cells than those usually observed in the Mediterranean at that time of the year (Marty et al., 2002). This is consistent with the observed increase of the opal flux after the event (data not shown), which indicates growth in the diatom species. Bigger cells, stimulated by the input of new nutrients, would be more prone to export, hence potentially inducing higher POC fluxes. The probable shift in biological communities that occurred after dust-fertilisation is also not detectable from satellite data from those oligotrophic waters. No significant increase in Chl- $a$ as indicated by satellite information after a dust event, should thus not be interpreted in such cases as a lack of marine biological response, as stated by Volpe et al. (2009).

\section{4 "Lithogenic events" and POC export efficiency}

Data from this study shows that for this 4-years time series, high POC fluxes were related to high marine lithogenic fluxes (Fig. 8), forming high export events named hereafter as "lithogenic events". This was especially the case for the previously described contrasting cases: March and December 2003, February 2004, and February and August 2005. As stated for the oceanic regions highly influenced by dust deposition (Neuer et al., 2004; Lee et al., 2009), such an association (POC - lithogenic matter) and subsequent export, would be mainly permitted by biological/physical aggregation processes and mineral ballasting (Boyd and Trull, 2007).

Indeed, several studies have proposed that ballast minerals (opal, carbonates and clay minerals) are able to scavenge organic matter (Hamm, 2002; Passow and de la Rocha, 2006; Engel, 2009), hence affecting the POC flux sinking velocity and its remineralisation rate. The mineral matrix would first provide a protection for the organic matter, and this would then act as a "glue" to bind particles together. Passow (2004) suggested that, rather than lithogenic particles, organic matter would be driving the aggregation process, the sinking POC scavenging small lithogenic particles in suspension in the water column. From those studies, it appears clear that whatever the aggregation catalyst is, the simultaneous presence (with a certain balance: Passow and de La Rocha, 2006) of organic matter and mineral particles is required to form any large and fast sinking particles. In situ organic matter quality was shown to vary seasonally at the DYFAMED site, influencing the sinking flux material composition and velocity (Bourguet et al., 2009; Wakeham et al., 2009). Furthermore, recent measurements showed that "old" organic matter, present in winter, (Marty et al., 1994), was more efficient in transferring aggregates to the deeper layers (Ploug et al., 2008). Organic matter quality may thus play an important role in the occurrence of "lithogenic events" but unfortunately it was not measured during this study.

In addition to this, several studies at the DYFAMED site have shown that zooplankton grazing and subsequent faecal pellet production may be a very efficient removal process of mineral particles from the surface waters (Fowler et al., 1987; Buat-Ménard et al., 1989). Unfortunately, only few zooplankton data are available for the time-series, and we do not know to what extent zooplankton can mediate high marine POC - lithogenic fluxes.

It is noteworthy that over the whole time-series, the highest POC fluxes were not related to high biological activity (i.e., spring bloom), as already observed at that site (Miquel et al., 1994; Migon et al., 2002), but rather to "lithogenic events". Fast sinking particles formed by the aggregation of organic matter and lithogenic material are less remineralised while transferring to the deeper layers (Hedges et al., 2000) than during the bloom period. Such "lithogenic events" can occur regularly (yearly, triggered by winter convection), or occasionally (triggered by Saharan events, in particular extreme ones).

Unpredictable Saharan events can play an important role in carbon export at the yearly scale: the very high POC export $\left(0.8 \mathrm{~g} \mathrm{C} \mathrm{m}^{-2}\right)$ measured after the extreme Saharan event of February 2004 represented $\sim 45 \%$ of the annual POC flux that year $\left(\sim 1.78 \mathrm{~g} \mathrm{C} \mathrm{m}^{-2}\right)$. Other "lithogenic events" (March 2003 and February 2005) that are attributed to the winter convection and not related to direct atmospheric dust deposition are also associated with high POC fluxes representing a large part of the annual export of POC $(\sim 30 \%)$. Thus, even in the absence of any extreme Saharan events, the annual winter convection leads to a more efficient particulate organic carbon export than the bloom period ( $\sim 25 \%$ of the total annual POC flux those years).

\subsection{The case of significant Saharan dust events with no induced lithogenic marine flux: June 2006}

In June 2006, during the stratification period (mixed layer $\sim 6 \mathrm{~m}$ ) a sequence of Saharan events occurred during a 10 days period of "sirocco" winds and brought $2.5 \mathrm{~g} \mathrm{~m}^{-2}$ of dust to the sea surface; the dust deposition occurred with a very low rainfall, from a few drops, up to short showers of less than $0.1 \mathrm{~mm}$ deposited. The filters did not display 


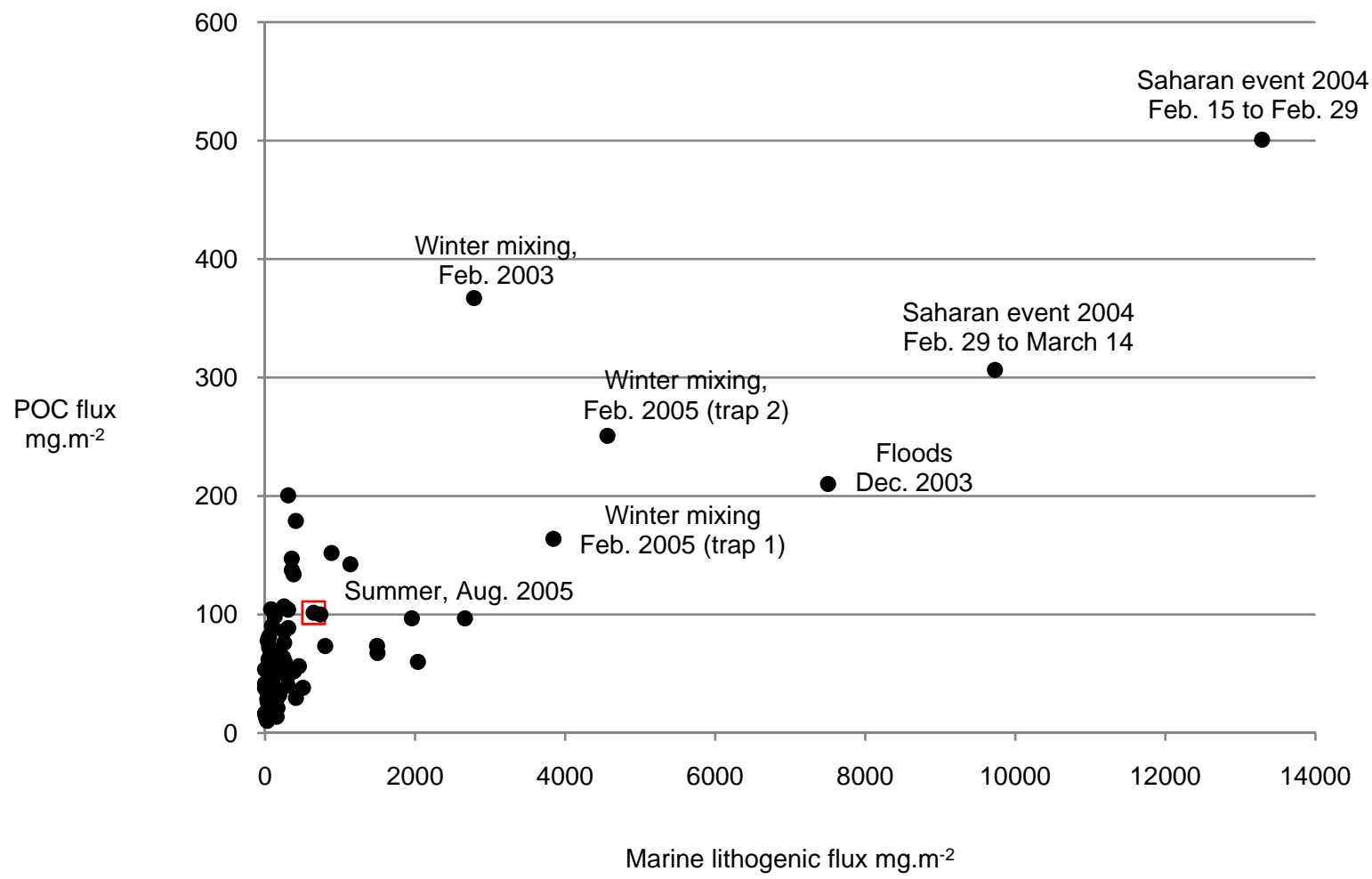

Fig. 8. Marine POC flux against marine lithogenic flux $\left(\mathrm{mg} \mathrm{m}^{-2}\right)$ at the DYFAMED site, $200 \mathrm{~m}$ depth, from 2003 to 2006.

any evidence of mixing with polluted material (such as black carbon). Despite evidence that these dust deposition events played a fertilising role to the bacterial community in the surface mixed layer at the DYFAMED site (Pulido-Villena et al., 2008), neither any increase of lithogenic (see Fig. 2), nor biogenic fluxes were noticed at $200 \mathrm{~m}$ during the following weeks. In order to explain this "non-export", three hypotheses are proposed. Firstly this 'pure Saharan event' (associated with a weak input of soluble inorganic nitrogen (Loÿe-Pilot et al., 1990) would have precluded any induced phytoplankton growth enhancement, and such low biological activity would have prevented any transfer via organic aggregates. This is the general case observed during the summer months with a strong stratification of the water column, when the mineral particles of small size are suspected to remain in the surface layer (Miquel et al., 1994; Migon et al., 2002). Secondly as already mentioned, in situ organic matter quality and low zooplankton activity could also be responsible for that non-export. Indeed either the seasonal variation of the organic matter quality or the low zooplanktonic abundance measured at the time of the 2006 Saharan event (L. Stemmann and L. Berline, personal communication), could have prevented any formation and export of aggregates. Finally it is possible that on occasions the Ligurian Current could have flowed through the DYFAMED area (evidence from SST data: L. Prieur, personal communication) with the consequence that the particles reaching the surface waters may actually be exported away from the study site by lateral advection before reaching the $200 \mathrm{~m}$ sampling depth.

\section{Conclusions}

During this 4-year study, the Saharan dust inputs over the Ligurian Sea displayed a temporal pattern and an annual mean flux very similar to previous observations in the same area, where short events of high magnitude (as in February 2004) drive the inter- and intra-annual variability. The seasonal pattern of total marine mass flux also fitted the previous description at the same site with the highest fluxes in winter and the lowest in summer. For the 4-year average, the lithogenic fraction represented $\sim 37 \%$ of the total marine mass flux with the same seasonal trend as the total mass flux.

Marine lithogenic particulate flux and dust deposition display different temporal variability, preventing any direct temporal comparison over the whole time series. The notion of "lithogenic events" was defined as the intense and concurrent export in the water column of POC and lithogenic material.

This study suggests that "lithogenic events" occur when there is a simultaneous presence of organic matter ("old" in winter, or freshly produced and induced by dust nutrient inputs in summer), lithogenic material (from "old" Saharan dust, that has been 'stored' in the upper water column or originating from a recent Saharan dust event or very occasionally from riverine flooding events), and most probably of 
zooplanktonic activity. These events are triggered either by hydrological processes (mixed layer deepening), or the sudden introduction of a large amount of Saharan dust particles (an extreme event), or by a "mixed" medium intensity Saharan event during the stratified water column period.

This study also suggests that those "lithogenic events" which are the most efficient in transferring POC to the deeper layers are not dependant of the seasonal spring bloom. This emphasises the role played by these occasional extreme Saharan events, and the usual winter convection, in the carbon export to the deep Mediterranean Sea.

Even if recent studies in the Mediterranean Sea, such as the MedFlux program, have improved our knowledge of the processes driving the POC export and the relationship between mineral ballast and organic matter, the present study shows that further research should be carried out to fully understand the concurrent marine particulate export of lithogenic material, in particular of atmospheric origin, and organic carbon. Furthermore, other parameters such as organic matter quality and zooplanktonic activity should be investigated.

Acknowledgements. The work presented here is part of the doctoral dissertation of E.T. (grant of the French Ministère de l'Education Nationale, de l'Enseignement Supérieur et de la Recherche). We thank J.-C. Marty and L. Coppola in charge of the DYFAMED program (funded by CNRS/INSU in the frame of the French-JGOFS (now PROOF) program. The IAEA is grateful for the support provided to its Marine Environment Laboratories by the Government of the Principality of Monaco. We also thank the captain and crew of the Tethys II for their work at sea. NASA data acknowledgments: The authors thank the Ocean Biology Processing Group (Code 614.2) at the GSFC, Greenbelt, MD 20771 , for the production and distribution of the ocean color data. The authors thank L. Stemmann and L. Berline for providing zooplankton data. We warmly thank Malcolm Woodward who kindly checked the manuscript for scientific English and two anonymous reviewers for their helpful feedbacks and suggestions.

Edited by: E. Marañón

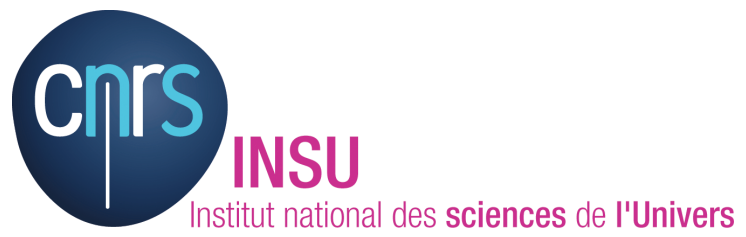

The publication of this article is financed by CNRS-INSU.

\section{References}

Alldredge, A., Passow, U., and Logan, E.: The abundance and significance of a class of large, transparent organic particles in the ocean, Deep Sea Res. I, 40, 1131-1141, 1993.

Andersen, V. and Prieur, L.: One-month study in the open NW Mediterranean Sea (DYNAPROC experiment, May 1995); overview of the hydrobiogeochemical structures and effects of wind events, Deep Sea Res. II, 47, 397-422, 2000.

Armstrong, R. A., Peterson, M. L., Lee, C., and Wakeham, S. G.: Settling velocity spectra and the ballast ratio hypothesis, Deep Sea Res. II, 56(18), 1740-1748, 2009.

Bergametti, G., Gomes, L., Remoudaki, E., Desbois, M., Martin, D., and Buat-Ménard, P.: Present transport and deposition patterns of African dusts to the North Western Mediterranean, in: Paleoclimatology and Paleometeorology: Modern and Past Patterns of Global Atmospheric Transport, edited by: Leinen, M. and Sarnthein, M., Kluwer Acad. Publ., Dordrecht, 227-252, 1989.

Béthoux, J. P. and Prieur, L.: Hydrologie et circulation en Mediterranée Nord-Occidentale, Pétroles et techniques, 299, 25-34, 1983.

Bishop, J. K. B., Davies, J. E., and Sherman, J. T.: Robotic Observations of Dust Storm Enhancement of Carbon Biomass in the North Pacific, Science, 298(5594), 817-821, 2002.

Boldrin, A., Miserocchi, S., Rabitti, S., Turchetto, M. M., Balboni, V., and Socal, G.: Particulate matter in the southern Adriatic and Ionian Sea: characterisation and downward fluxes, J. Mar. Syst., 33-34, 389-410, 2002.

Bonnet, S., Guieu, C., Chiaverini, J., Ras, J., and Stock, A.: Effect of atmospheric nutrients on the autotrophic communities in a low nutrient, low chlorophyll system, Limnol. Oceanogr., 50(6), 1810-1819, 2005.

Bonnet, S. and Guieu, C.: Atmospheric forcing on the annual iron cycle in the western Mediterranean Sea: A 1-year survey, J. Geophys. Res., 111, C09010, doi:10.1029/2005JC003213.2006.

Bory, A., Jeandel, C., Leblond, N., Vangriesheime, A., Khripounoffe, A., Beaufort, L., Rabouille, C., Nicolas, E., Tachikawag, K., Etcheberh, H., and Buat-Menard, P.: Downward particle fluxes within different productivity regimes off the Mauritanian upwelling zone (EUMELI program), Deep Sea Res. I, 48, 2251-2282, 2001.

Bosc, E., Bricaud, A., and Antoine, D.: Seasonal and interannual variability in algal biomass and primary production in the Mediterranean Sea, as derived from 4 years of SeaWiFS observations, Global Biogeochem. Cycles, 18, GB1005, doi:10.1029/2003GB002034, 2004.

Bourguet, N., Gotux, M., Ghiglione, J.-F., Pujo-Pay, M., Mével, G., Momzikoff, A., Mousseau, L., Guigue, C., Garcia, N., Raimbault, P., Pete, R., Oriol, L., and Lefèvre, D.: Lipid biomarkers and bacterial lipase activities as indicators of organic matter and bacterial dynamics in contrasted regimes at the DYFAMED site, NW Mediterranean, Deep Sea Res. II, 56(18), 1454-1469, 2009.

Boyd, P. W. and Trull, T.: Understanding the export of biogenic particles in oceanic waters: Is there consensus?, Progr. in Ocean., 72, 276-312, 2007.

Buat-Ménard, P., Davies, P. J., Remoudaki, E., Miquel, J.-C., Bergametti, G., Lamber, C. E., Ezat, E., Quétel, C. R., La Rosa, J., and Fowler, S. W.: Non-steady-state biological removal of atmospheric particles from Mediterranean surface waters, Nature, 340, 131-133, 1989.

Burd, A. B. and Jackson, G. A.: Particle Aggregation, Annu. Rev. Mar. Sci., 1, 65-90, 2009.

Conte, M. H., Ralph, N., and Ross, E. H.: Seasonal and interannual variability in deep ocean particle fluxes at the Oceanic Flux Program (OFP)/Bermuda Atlantic Time Series (BATS) site in the 
western Sargasso Sea near Bermuda, Deep Sea Res. II, 48, 14711505, 2001.

D’Ortenzio, F., Iudicone, D., Boyer Montegut, C., Testor, P., Antoine, D., Marullo, S., Santoleri, R., and Madec, G.: Seasonal variability of the mixed layer depth in the Mediterraenan sea as derived from in situ profiles, Geoph. Res. Lett., 32, L12605, doi:10.1029/2005GL.022463, 2005.

Duce, R. A., Liss, P. S., Merrill, J. T., Atlas, E. L., Buat-Menrad, P., Hicks, B. B., Miller, J. M., Prospero, J. M., Arimoto, R., Church, T. M., Ellis, W., Galloway, J. N., Hansen, L., Jickells, T. D., Knap, A. H., Reinhardt, K. H., Schneider, B., Soudine, A., Tokos, J. J., Tsunogai, S., Wollast, R., and Zhou, M.: The atmospheric input of trace species in the world ocean, Global Biogeochem. Cycles, 5, 195-259, 1991.

Engel, A., Szlosek, J., Abramson, L., Liu, Z., and Lee, C.: Investigating the effect of ballasting by $\mathrm{CaCO}_{3}$ in Emiliana huxley: I. Formation, settling velocities and physical properties of aggregates, Deep Sea Res. II, 56(18), 1396-1407, 2009.

Fabres, J., Calafat, A., Sanchez-Vidal, A., Canals, M., and Heussner, S.: Composition and spatio-temporal variability of particle fluxes in the Western Alboran Gyre, Mediterranean Sea, J. Mar. Syst., 33-34, 431-456, 2002.

Fowler, S.W., Buat-Ménard, P., Yokoyama, Y., Ballestra, S., Holm, E., Van Nguyen, H.: Rapid removal of Chernobyl fallout from Mediterranean surface waters by biological activity, Nature, 329(6134), 56-58, 1987.

Gehlen, M., Beck, L., Calas, G., Flank, M.-A., Van Bennekom, A. J., and Van Beusekom, J. E. E.: Unraveling the atomic structure of biogenic silica: Evidence of the structural association of $\mathrm{Al}$ and $\mathrm{Si}$ in diatom frustules, Geoch. Cosm. Acta, 66(9), 16011609, 2002.

Goutx, M., Momzikoff, M., Striby, L., Andersen, V., Marty, J.-C., and Vescovali, I.: High-frequency fluxes of labile compounds in the central Ligurian Sea, northwestern Mediterranean, Deep Sea Res. I, 47, 533-556, 2000.

Guerzoni, S., Chester, R., Dulac, F., Herut, B., Loÿe-Pilot, M. D., Measures, C., Migon, C., Molinaroli, E., Moulin, C., Rossini, P., Saydam, C., Soudine, A., and Ziveri, P.: The role of atmospheric deposition in the biogeochemistry of the Mediterranean Sea, Progress in Oceanography, 44, 147-190, 1999.

Guieu, C., Loÿe-Pilot, M. D., Ridame, C., and Thomas, C.: Chemical characterization of the Saharan dust end-member: Some biogeochemical implications for the western Mediterranean Sea, J. Geophys. Res., 107(D15), 4258, doi:10.1029/2001JD000582, 2002.

Guieu, C., Roy-Barman, M., Leblond, N., Jeandel, C., Souhaut, M., Le Cann, B., Dufour, A., and Bournot, C.: Vertical particle flux in the northeast Atlantic Ocean (POMME experiment), J. Geophys. Res., 110, 1-21, 2005.

Guieu, C., Loÿe-Pilot, M.-D., Benyaya, L., and Dufour, A.: Spatial variability of atmospheric fluxes of metals ( $\mathrm{Al}, \mathrm{Fe}, \mathrm{Cd}, \mathrm{Zn}$ and $\mathrm{Pb}$ ) and phosphorus over the whole Mediterranean from a oneyear monitoring experiment; biogeochemical implications, Mar. Chem., doi:10.1016/j.marchem.2009.02.004, in press, 2010.

Guidi-Guilvard, L.: DYFAMED-BENTHOS, a long time-series benthic survey at 2347-m depth in the north-western Mediterranean: general introduction, Deep Sea Res. II, 49, 2183-2193, 2002.

Hamm, C. E.: Interactive aggregation and sedimentation of diatoms and clay-sized lithogenic material, Limnol. Oceanogr., 47(6), 1790-1795, 2002.

Han, Q., Moore, J. K., Zender, C., Measures, C., and Hydes, D. J.: Constraining oceanic dust deposition using surface ocean dissolved Al, Global Biogeoch. Cycles, 22, GB2003, doi:10.1029/2007GB002975, 2008.

Hedges, I. H., Eglinton, G., Hatcher, P. G., Kirchman, D. L., Arnosti, C., Derenne, S., Evershed, R. P., Ogel-Knabner, I. K., De Leeuw, J. W., Littke, R., Michaelis, W., and Rullkotter, J.: The molecularly uncharacterized component of nonliving organic matter in natural environments, Organic Geochem., 31, 945-951, 2000.

Herut, B., Collier, R., and Krom, M. D.: The role of dust in supplying nitrogen and phosphorus to the Southeast Mediterranean, Limnol. Oceanogr., 47(3), 870-878, 1999.

Hydes, D. J.: Aluminum in Seawater: Control by Inorganic Processes, Science, 205, 1260-1262, 1979.

Jackson, G. A.: Effect of mixed layer depth on phytoplankton removal by coagulation and on the critical depth concept, Deep Sea Res. I, 55, 766-776, 2008.

Journel, B.: Apports atmosphériques de métaux en mer Ligure: caractérisation géochimique et devenir dans la colonne d'eau (site DYFAMED), PhD thesis, University of Aix-Marseille, 344 pp, 1998.

Karl, D. M., Christian, J. R., Dore, J. E., Hebel, D. V., Letelier, R. M., Tupas, L. M., and Winn, C. D.: Seasonal and interannual variability in primary production and particle flux at Station ALOHA, Deep Sea Res. II, 43, 2-3, 539-568, 1996.

Klein, C., Dolan, J., and Rassoulzadegan, F.: Experimental examination of the effects of rainwater on microbial communities in the surface layer of the NW Mediterranean Sea, Marine EcologyProgress Series, 158, 41-50, 1997.

Kouvarakis, G., Mihalopoulos, N., Tselepides, A., and Stavrakakis, S.: On the importance of atmospheric inputs of inorganic nitrogen species on the productivity of the Eastern Mediterranean Sea, Global Biogeochem. Cycles, 15(4), 805-817, 2001.

Krom, M. D., Herut, B., and Mantoura, R. F. C.: Nutrient budget for the Eastern Mediterranean: Implications for P limitation, Limnol. Oceanogr., 49, 1582-1592, 2004.

Lee, C., Peterson, M. L., Wakeham, S. G., Armstrong, R. A., Cochran, J. K., Miquel, J. C., Fowler, S. W., Hirschberg, D., Beck, A., and Xue, J.: Particulate organic matter and ballast fluxes measured using time-series and settling velocity sediment traps in the northwestern Mediterranean Sea, Deep Sea Res. II, 56(18), 1420-1436, 2009.

Lévy, M., Mémery, L., and André, J.-M.: Simulation of primary production and export fluxes in the Northwestern Mediterranean Sea, J. Mar. Res., 56, 197-238, 1998.

Loÿe-Pilot, M. D., Martin, J. M., and Morelli, J.: Influence of Saharan dust on the rain acidity and atmospheric input to the Mediterranean, Nature, 321, 427-428, 1986.

Loÿe-Pilot, M. D. and Morelli, J.: Fluctuations of inoic composition of precipitations collected in Corsica related to changes in the origins of incoming aerosols, J. Aerosol Sci., 19(5), 577-585, 1988.

Loÿe-Pilot, M. D., Martin, J. M., and Morelli, J.: Atmospheric input of inorganic nitrogen to the Western Mediterranean, Biogeochem., 9, 117-134, 1990.

Loÿe-Pilot, M. D. and Martin, J. M.: Saharan dust input to the 
Western Mediterranean: and eleven years record in Corsica, in: The Impact of Desert Dust Across the Mediterranean, edited by: Guerzoni, S. and Chester R., Kluwer A.P., Dordrecht, 191-199, 1996.

Mackenzie, F. T., Soffyn, M., and Wollast, R.: Aluminum in seawater: control by biological activity, Science, 199, 680-682, 1978.

Markaki, Z., Oikonomou, K., Kocak, M., Kouvarakis, G., Chaniotaki, A., Kubilay, N., and Mihalopoulos, N.: Atmospheric deposition of inorganic phosphorus in the Levantine Basin, eastern Mediterranean: Spatial and temporal variability and its role in seawater productivity, Limnol. Oceanogr., 48(4), 1557-1568, 2003.

Martin, J. M. and Windom, H. L.: Present and future roles of ocean margins in regulating marine biogeochemical cycles of trace elements, In R. F. C. Mantoura et al., Ocean Margin Processes in Global Change, Wiley, 45-67, 1991.

Marty, J.-C., Nicolas, E., Miquel, J. C., and Fowler, S. W.: Particulate fluxes of organic compounds and their relationship to zooplankton faecal pellets in the north-western Mediterranean Sea, Mar. Chem., 46(3), 387-405, 1994.

Marty, J.-C., Chiavérini, J., Pizay, M. D., and Avril, B.: Seasonal and interannual dynamics of nutrients and phytoplankton pigments in the western Mediterranean Sea at the DYFAMED timeseries station (1991-1999), Deep Sea Res. II, 49, 1965-1985, 2002.

Measures, C.: The distribution of $\mathrm{Al}$ in the IOC stations of the eastern Atlantic between $30^{\circ} \mathrm{S}$ and $34^{\circ} \mathrm{N}$, Mar. Chem., 49, 267-281, 1995.

Migon, C. and Sandroni, V.: Phosphorus in rainwater: Partitioning inputs and impact on the surface coastal ocean, Limnol. Oceanogr., 44(4), 1160-1165, 1999.

Migon, C., Sandroni, V., Marty, J. C., Gasser, B., and Miquel, J. C.: Transfer of atmospheric matter through the euphotic layer in the northwestern Mediterranean: seasonal pattern and driving forces, Deep Sea Res. II, 49, 2125-2141, 2002.

Miquel, J. C., Fowler, S. W., La Rosa, J., and Buat-Menard, P.: Dynamics of the downward flux of particles and carbon in the open northwestern Mediterranean Sea, Deep Sea Res. I, 41(2), 243-261, 1994.

Miserocchi, S., Faganeli, J., Balboni, V., Heussner, S., Monaco, A., and Kerherve, P.: Characteristics and sources of the settling particulate organic matter in the South Adriatic basin, Org. Geochem., 30, 411-421, 1999.

Monaco, A., Durrieu de Madron, X., Radakovitch, O., Heussner, S., and Carbonne, J.: Origin and variability of downward biogeochemical fluxes on the Rhone continental margin (NW mediterranean), Deep Sea Res. I, 46, 1483-1511, 1999.

Moutin, T., Thingstad, T. F., Van Wambeke, F., Marie, D., Slawik, G., Raimbault, P., and Claustre, H.: Does competition for nanomolar phosphate supply explain the predominance of the cyanobacterium Synechococcus?, Limnol. Oceanogr., 47(5), 1562-1567, 2002.

Neuer, S., Torres-Padron, M. E., Gelado-Caballero, M. D., Rueda, M. J., Hernandez-Brito, J., Davenport, R., and Wefer, G.: Dust deposition pulses to the eastern subtropical North Atlantic gyre: Does ocean's biogeochemistry respond?, Global Biogeochem. Cycles, 18, GB4020, doi:10.1029/2004GB002228, 2004.

Passow, U.: Switching perspectives: Do mineral fluxes determine particulate organic carbon fluxes or vice versa?, Geochem.
Geoph. Geosyst., 5(4), Q04002, doi:10.1029/2003GC000670, 2004.

Passow, U. and De La Rocha, C.: Accumulation of mineral ballast on organic aggregates, Global Biogeochem. Cycles, 20, GB1013, doi:10.1029/2005GB002579, 2006.

Ploug, H., Hvitfeld Iversen, M., and Fischer, G.: Ballast, sinking velocity, and apparent diffusivity within marine snow and zooplankton fecal pellets: Implications for substrate turnover by attached bacteria, Limnol. Oceanogr., 53(5), 1878-1886, 2008.

Pulido-Villena, E., Wagener, T., and Guieu, C.: Bacterial response to dust pulses in the western Mediterranean: Implications for carbon cycling in the oligotrophic ocean, Global Biogeochem. Cycles, 22, GB1020, 1-12, doi:10.1029/2007GB003091, 2008.

Quétel, C. R., Remoudaki, E., Davies, J. E., Miquel, J. C., Fowler, S. W., Lambert, C. E., Bergametti, G., and Buat-Menard, P.: Impact of atmospheric deposition on particulate iron flux and distribution in northwestern Mediterranean waters, Deep Sea Res. I, 40(5), 989-1002, 1993.

Ridame, C.: Rôle des apports atmosphériques d'origine continentale dans la biogéochimie marine: Impact des apports sahariens sur la production primaire en Méditerrannée, $\mathrm{PhD}$ thesis, University of Pierre et Marie Curie, Paris 6, 253 pp, 2001.

Sanchez-Vidal, A., Calafat, A., Canals, M., Frigola, J., and Fabres, J.: Particle fluxes and organic carbon balance across the Eastern Alboran Sea (SW Mediterranean Sea), Cont. Shelf Res., 25, 609628, 2005.

Stavrakakis, S., Chronis, G., Tselepides, A., Heussner, S., Monaco, A., and Abassi, A.: Downward fluxes of settling particles in the deep Cretan Sea (NE Mediterranean), Progr. Oceanogr., 46, 217240, 2000.

Stemmann, L.: Analyse spatio-temporelle de la matière particulaire déterminée par une nouvelle technique vidéo en Méditerranée Nord-Occidentale, Ph.D. thesis, University of Pierre et Marie Curie, paris 6, 200 pp, 1998.

Stemmann, L., Gorsky, G., Marty, J.-C., Gasser, B., and Miquel, J.-C.: Four-year study of large-particle vertical distribution (0$1000 \mathrm{~m}$ ) in the NW Mediterranean in relation to hydrology, phytoplankton and vertical flux, Deep Sea Res. II, 49, 2143-2162, 2002.

Thingstad, T. F., Zweifel, U. L., and Rassoulzadegan, F.: P limitation of heterotrophic bacteria and phytoplankton in the northwest Mediterranean, Limnol. Oceanogr., 43, 88-94, 1998.

Tomadin, L. and Lenaz, R.: Eolian dust over the Mediterranean and their contribution to the present sedimentation, in: Paleoclimatology and Paleometeorology: Modern and Past Patterns of Global Atmospheric Transport, edited by: Leinen, M. and Sarnthein, M., Kluwer Acad. Publ., Dordrecht, 267-282, 1989.

Volpe, G., Banzon, V. F., Evans, R. H., Santoreli, R., Mariano, A. J., and Sciarra, R.: Satellite observations of the impact of dust in a low-nutrient, low-chlorophyll region: Fertilisation or artifact?, Global Biogeochem. Cycles, 23, GB3007, doi:10.1029/2008GB003216, 2009.

Wakeham, S. G., Lee, C., Peterson, M. L., Liu, Z., Szlosek, J., Putnam, I. F., and Xue, J.: Organic biomarkers in the twilight zone Time series and settling velocity sediment traps during MedFlux, Deep Sea Res. II , 5(18), 1437-1453, 2009.

Wedepohl, K. H.: The composition of the continental crust, Geochimica and Cosmochimica Acta, 59, 1217-1232, 1995.

Zuniga, D., Calafat, A., Sanchez-Vidal, A., Canalsa, M., Price, B., 
Heussner, S., and Miserocchi, S.: Particulate organic carbon budget in the open Algero-Balearic Basin (Western Mediterranean): Assessment from a one-year sediment trap experiment, Deep Sea Res. I, 54, 1530-1548, 2007.
Zuniga, D., Calafat, A., Heussner, S., Miserocchi, S., SanchezVidal, A., Garcia-Orellana, J., Canals, M., Sanchez-Cabeza, J. A., Carbonne, J., Delsaut, N., and Saragoni, N.: Compositional and temporal evolution of particle fluxes in the open AlgeroBalearic basin (Western Mediterranean), J. Mar. Syst., 70(1-2), 196-214, 2008. 